\title{
Explaining the components of situated cognition theory-based teacher education
}

\author{
Erfane Ghasempour ${ }^{1}$, Mahmoud Talkhabi $^{2 *}$ (iD , Marzieh Dehghani ${ }^{3}$, Keyvan Salehi ${ }^{3}$
}

1. PhD Candidate in Curriculum Studies, Tehran University, Tehran, Iran

2. Assistant Professor of Department of Educational Sciences, Farhangian University and Institute for Cognitive Science Studies (ICCS), Tehran, Iran

3. Assistant Professor of Educational Measurement and Evaluation, Faculty of Psychology and Education, University of Tehran, Iran

Recieved: 16 Jul. 2018

Revised: 13 May 2019

Accepted: 23 May 2019

\section{Keywords \\ Cognitive science \\ Situated cognition \\ Teacher education \\ Curriculum \\ Component}

\section{Corresponding author}

Mahmoud Talkhabi, Assistant

Professor of Department of Educational Sciences, Farhangian University and Institute for Cognitive Science Studies (ICCS), Tehran Iran

\section{Email: Talkhabi@iricss.org}

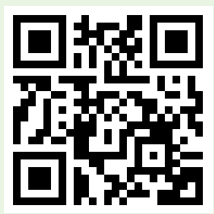

\section{Abstract}

Introduction: The present study is an attempt to explain the components of the teacher education curriculum based on the situated cognition theory. This theory, with a new attitude to the cognition and learning, believes that these two categories have been applied in specific situations. Therefore, people need to be involved in real-world situations to gain authentic knowledge.

Methods: Based on the perspective of situated cognition theory, the four main components of the teacher education curriculum, including teaching-learning opportunities, learning strategies, and evaluation were explained using theoretical inquiry. A prescriptive model of teacher education curriculum was presented in the form of teaching and learning strategies. This prescriptive model underlies the two concepts of cognitive apprenticeship and community of practice using learning opportunities to achieve the goals of the curriculum. The hidden evaluation component in the prescriptive model carried out to assess the process and output results.

Results: The findings of the present study were discussed in terms of components such as goals, teaching-learning opportunities, learning strategies, and evaluation. In the goals section, four goals were focused on transferring well-appointed and applied knowledge to learners, social construction of meaning, training efficient and productive professional teachers, and shaping learners' professional identities. Learning opportunities have focused on doing authentic practices, discourse, narrative writing, scenario building, design, and visualization of their professional perceptions. Learning opportunities at the heart of two learning strategies, including cognitive apprenticeship, and communities of practice will accomplish the mentioned goals. Finally, the validated and authentic evaluation was proposed to evaluate the designed curriculum.

Conclusion: Researchers believe that the application of the curriculum framework based on the situated cognition theory in teacher education contributes to reducing the gap between theoretical and practical knowledge, and as a result, between theory and practice. 


\title{
تبيين مولفه هاى برنامه درسى تربيت معلم بر مبناى نظريه شناخت موقعيتى

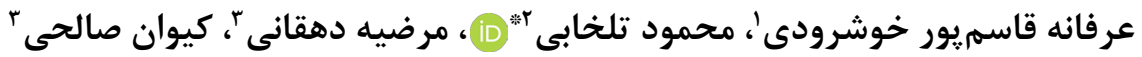

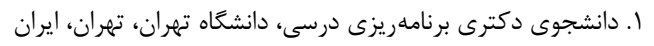

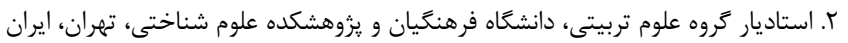

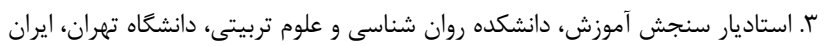

\begin{abstract}
בris
مقلهمه: اين مقاله به تبيين مولفههاى برنامه درسى تربيت معلم بر مبناى نظريه شناخت موقعيتى برداخته است. اين نظريه با نخرش جديد به يادكيرى و شناخت معتقد است كه شناخت و يادكيرى در موقعيت هاى ويزه مورد كاربرد آن واقع شدهاند. بنابراين افراد براى كسب دانش معتبر بايد در موقعيتهاى واقعى مشاركت و تعامل داشته باشند. روش كار: بر اساس خشم/انداز نظريه شناخت موقعيتى، با استفاده از روش يُوهش نظريهاى، جهار مولفه اصلى برنامه درسى تربيت معلم هدف، فرصتهاى ياددهى_يادكيرى، راهبردهاى يادكيرى و ارزشيابى تبيين شد. ارائه مدل تجويزى برنامه درسى تربيت معلم در قالب راهبردهاى ياددهى و يادكيرى ارائه شد. اين مدل تجويزى در بركيرنده دو مفهوم كارورزى شناختى و جوامع عمل، با به كاركيرى فرصتهاى يادكيرى در راستاى تحقق اهداف برنامه درسى اقدام مىنمايد و مولفه ارزشيابى مستتر در مدل تجويزى براى ارزيابى فرآيند و برونداد نتايج صورت مى يافته ها: يافتههاى يروهش حاضر در ذيل مولفههاى هدف، فرصتهاى ياددهى_يادكيرى، راهبردهاى يادگيرى و ارزشيابى بحث شد. در بخش اهداف به جهار هدف، انتقال دانش كاربردى و مستحكم به فراكيران، ساخت اجتماعى معنا، تربيت معلمان حرفهاى كارا و مولد و شكلدهى هويت حرفهاى فراگيران اشاره شد. فرصتهاى يادكيرى به مواردى جون انجام فعاليتهاى اصيل، كفتمان، روايت يردازى، سناريو سازى، طراحى و تصويرسازى از ادراى حرفهاى خود يرداخته است. فرصت هاى يادكيرى در بطن دو راهبرد يادكيرى كارورزى شناختى و جوامع عمل تحقق اهداف مورد نظر را محقق مىسازد. در نهايت، ارزشيابى معتبر و اصيل جهت ارزيابى برنامه درسى طراحى شده ييشنهاد داده شد. نتيجه كَيرى: يُروهشَران معتقدند به كارگيرى خارجوب برنامه درسى ارائه شده بر مبناى نظريه شناخت موقعيتى در تربيت معلم به كاهش فاصله دانش نظرى و عملى و در نتيجه نظريه و عمل كمك خواهد كرد.
\end{abstract}

دريافت:

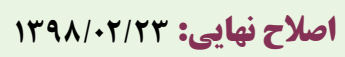

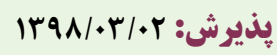

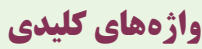
علوم شناختى شناخت موقعيتى ت ترنى تربيت معلم

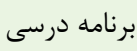
مولفه

نويسنله مسئول محمود تلخابى، استاديار گروه علوم تربيتى،

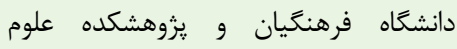
شناختى، تهران، ايران ايميل:Talkhabi@iricss.org

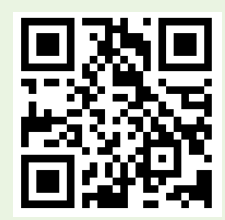

doi doi.org/10.30699/icss.21.4.58

مقدمه

دليل تاكيد بيش از حد بر فرآيندهاى ذهنى، در تبيين نحوه يادگيرى

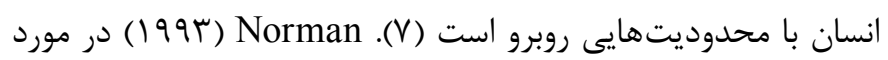
تفاوت بين اين دو نظريه بيان مى كند كه بر طبق ديدگاه يردازش اطلاعات، تمامى عملكردها در درون سر واقع شده است و تمايز طبيعى بين جيزهاى بيرون از ذهن و فرآيندهايى كه در درون آن شكل
نظريه شناخت موقعيتى (Situated Cognition) در دهه •191 توسط افرادى هون Brown و همكاران (1)، Lave و

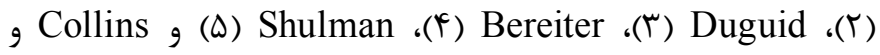
همكاران (9) به عنوان واكنشى به نظريه يردازش اطلاعات به ظهور رسيد. طرفداران اين نظريه معتقدند كه الخوى يردازش اطلاعات به 
بر همين مبنا، يادگيرى توصيف شده از ديدگاه شناخت موقعيتى به عنوان يك فعاليت اجتماعى است كه در تركيبى از ذهن، بدن، فعاليت

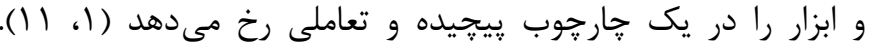
در حالى كه رويكردهاى علوم شناختى از جمله يردازش اطلاعات و شناخت نمادين، بر فرآيندهاى فردى متمركز است كه از بسترهاى فرهنگَى و فيزيكى مجزا هستند و دانش و اطلاعات ساختار خنثى دارند. نظريههاى جديد در حيطه شناخت، ابزارها، افراد و فرهنت را واسطه هاى عمده سازنده معنى مى دانند (Y). فعاليتها، مفاهيمى و فرهنگ سه عنصر مهرم در نظريه شناخت موقعيتى محسوب مىشوند كه به صورت يكيارجه در سيستم گستردهتر با هم مرتبط هستند و يادگيرى هر سه را در بر مى گيرد (l، ץ). Lave به عنوان سردمدار اين نظريه، يادگيرى موقعيتى را به عنوان يادگيرى از طريق تعاملات اجتماعى و فرهنكى در موقعيتهاى معتبر در نظر مى گيرد كه بخش كان جدايى نايذير از فعاليت اجتماعى است. همانطور كه Brown و Du اشاره كردهاند: يادگيرى به عنوان ابخشى از يك فرآيند ناگزير guid

ناتمام، اما پييوسته است كه در طول زندكى ادامه مى يابده (T (I). دانش، يادگيرى و شناخت ساختارهاى اجتماعى بيان شده در اعمال مردمى است كه در اجتماع تعامل دارند. از طريق اين اعمال است كه شناخت تصويب، آشكار و ساخته مىشود؛ بدون كنش هيج دانستن و شناختى وجود ندارد (^). از نظر Fاه شناخت موقعيتى، دانش در شرايط و موقعيتهاى خاص زمينهسازى شده است. دانش به موقعيتهاى واقعى وابسته است و در فعاليت افراد، زمينه و فرهنگى كه در آن توسعه و استفاده مى شود، واقع شده است ( (1). بر طبق نظر Resnick، اهر كنش شناختى بايد به عنوان يك ياسخ مشخص به يك مجموعه خاص از شرايط در نظر گرفته شوده (سا). كاربرد دانش در موقعيت خاص توسط افراد، ابزارها، مصنوعات فرهنگَى و كنش هاى مرتبط با آن موقعيت معين و تعديل مى شود. مدل شماره ( (1) بيان كننده نخاه نظريه

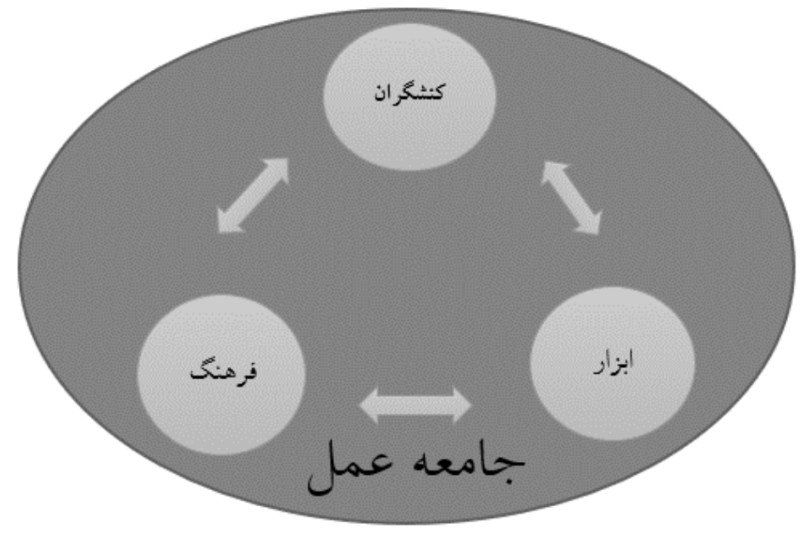

شكل 1. شماى مفاهيم پايه نظريه شناخت موقعيتى
مى گيرد، وجود دارد. در حالى كه اقدامات بسيارى در وسعت جهان و در گروههاى اجتماعى_فرهنكى وجود دارد، اما فر آيندهاى شناختى در كاسه سر اشخاص رخ مى دهد. بنابراين تلاشى براى فهمم فر آيندهاى ذهنى درونى و ماهيت انتقال درون ابرون اشخاص صورت گرفته است. نظريه شناخت موقعيتى در ياسخ به نظريه يردازش اطلاعات بسيارى

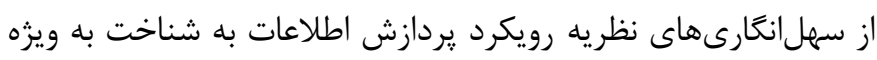
اتكاى اين نظريه به توصيفات ذخيره شده قوانين و اطلاعات، تمركز بر استدلال و تفكر آكاهانه و غفلت از زمينههاى فيزيكى و فرهنكى را اصلاح نمود (1). در مقالهاى كه در سال 919 ا توسط Collins و همكاران، مفهوم اشناخت موقعيتى" و زيامدهاى آن براى يادگيرى مطرح شده است. در اين مقاله، رويكرد غالب براى اكتساب دانش در مدارس با توجه به فعاليت و زمينه را به عنوان رويكرد 》مفيد آموزشى" معرفى كردهاند: الفعاليتى كه دانش در آن توسعه داده شده و مستقر شده است، جدا از يادكيرى و يا شناخت نيست. همجنين خنثى نيست، بلكه بخش جدايى نايذيرى از آنجه آموخته مى شود، است. موقعيتها

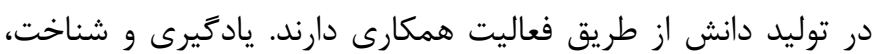
اساسا موقعيتى هستند ( ())، درك اينكه جٍكونه يادگيرى رخ مى دهد، جهت طراحى و ارزيابى راهبردهاى آموزشى ضرورى است. فرضيه هاى آموزشى در مورد يادگيرى و توسعه دانش بر طراحى محيطهاى ياد گيرى و فعاليتها تأثير مى گذارد. شناخت موقعيتى به عنوان يكى از متاخرترين نظريه هاى حوزه نظريه هاى يادگيرى، درك اصلاح شدهاى از يادكيرى ارائه مى دهد كه در آن يادگيرى موقعيتى، و وابسته به زمينه است (1) (9- (9). اين نظريه ها مفروضات هستهاى در مورد يادگيرى و شناخت انسان را به اشتراى مى گذارد؛ دانشى كه در زمينه واقع شده است. طرفداران نظريه شناخت موقعيتى به شناخت اجتماعى_فرهنكَى باور دارند. به باور آنها ذهن در حالت انزوا و به دور از الزامات موقعيتى به معناسازى نمييردازد، بلكه شناخت محصول بودن ما در اجتماع فرهنكى است ( (1). فعاليتها، مفاهيم و فرهنگ سه عنصر مهمم در نظريه شناخت موقعيتى محسوب مىشوند كه به صورت يكيار جه در سيستم گستردهتر با هم مرتبط مىباشند و يادگيرى هر سه را در بر مى گيرد ( (، ؟). در حالى كه Brown و همكاران بسيارى از روشهاى آموزشى موجود هرد را نقد مىنمايند و معتقدند كه اين روشها بين دانستن و انجام دادن

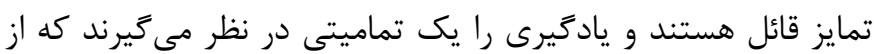
لحاظ نظرى از موقعيت هايى كه در آن آموخته مى شود، مستقل است. به اعتقاد آنان موقعيتها از طريق فعاليتها در توليد دانش همكارى دارند و يادكيرى و دانش اساساً موقعيتى است (1). 
يادگيرندگان اغلب نمىتوانند دانش تئورى كسب شده را در هنگام

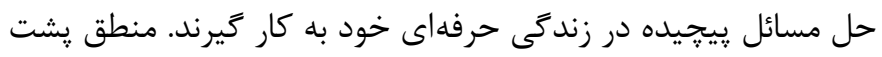

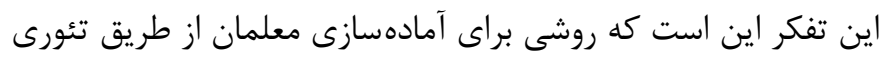

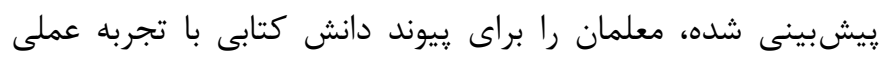

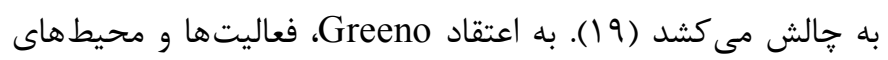

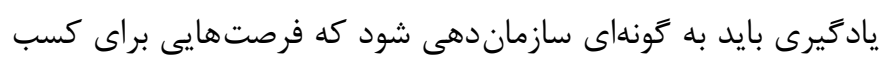

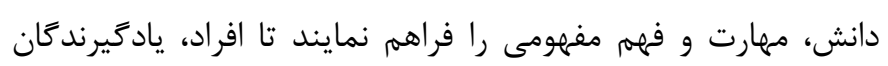

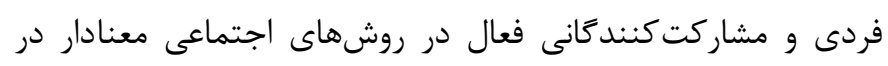

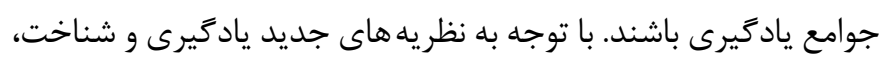

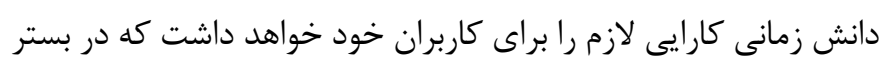

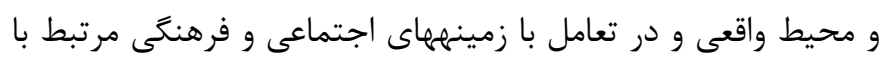

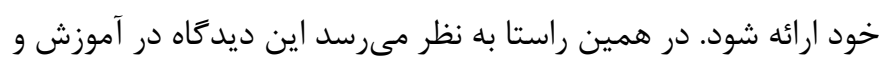

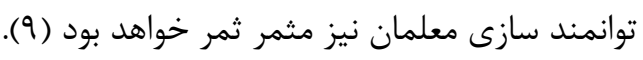

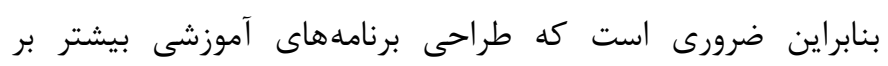

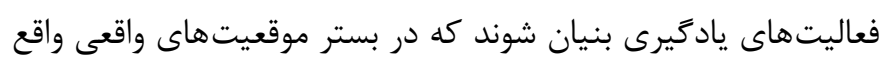

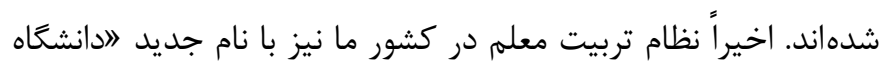

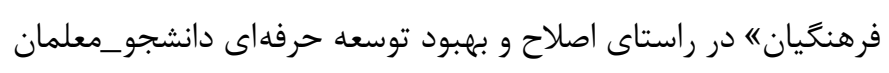

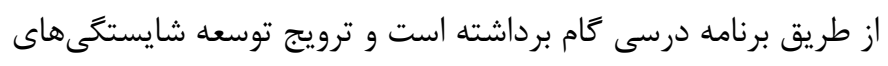

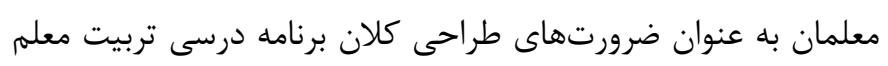

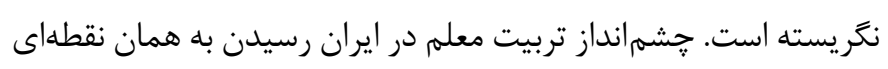

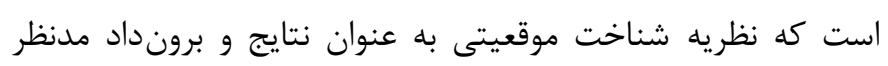

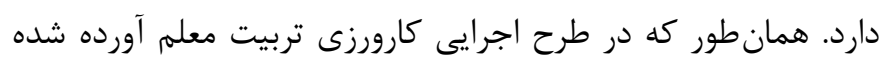

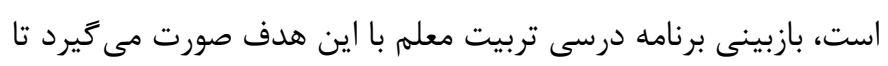

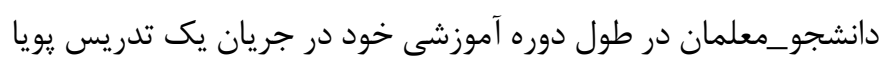

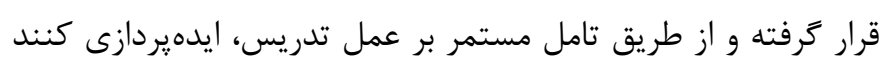

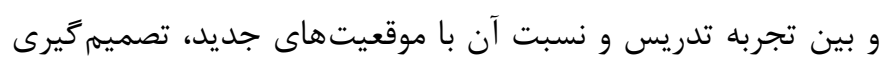

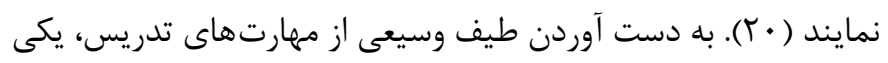

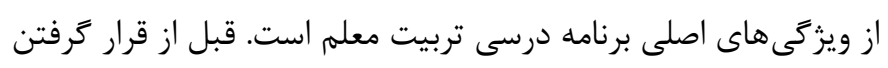

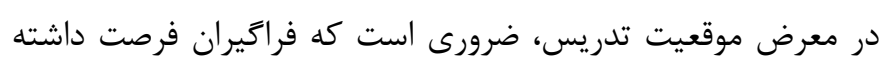

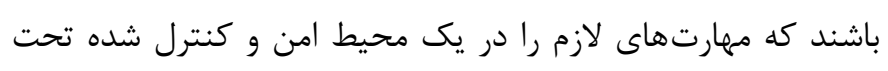

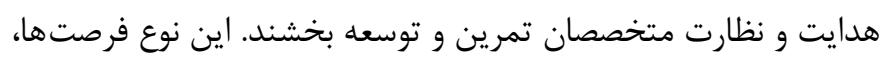

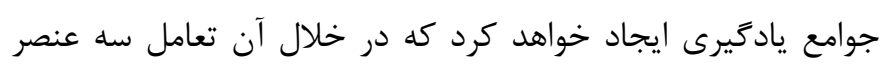

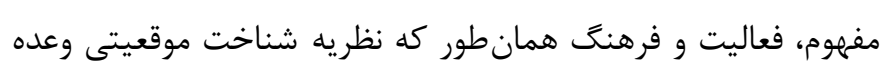

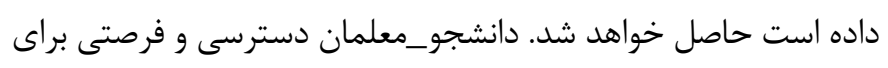

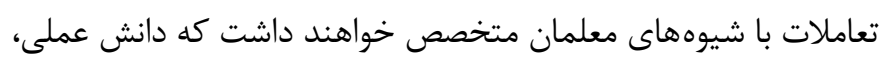

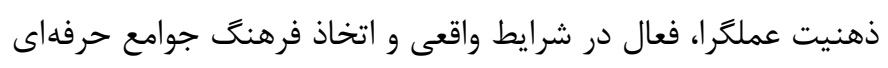
را ممكن خواهد كرد. بنابراين نظريه شناخت موقعيتى با فراهم آوردن
شناخت موقعيتى به شكل گيرى يادگيرى از منظر نظريه يردازان عمده

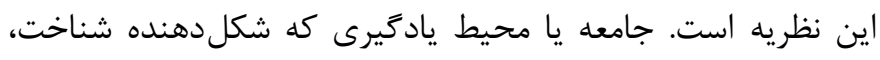

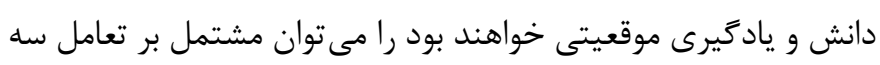

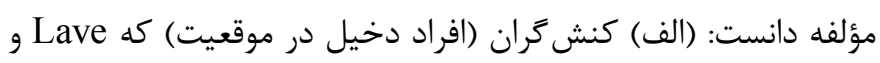

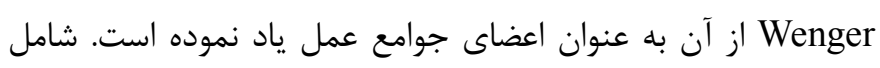

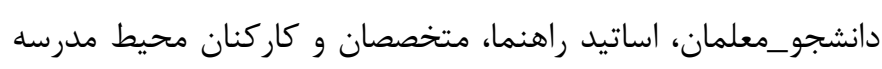
(يرسنل جانبى)؛ (ب) ابزار و مصنوعات فيزيكى و فرهنگى (دانش مستتر

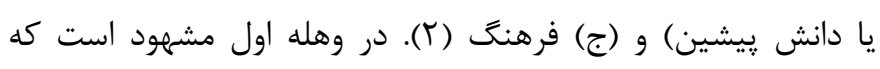

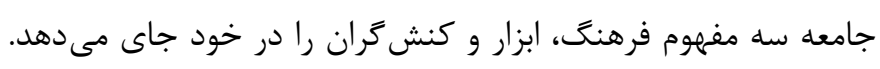

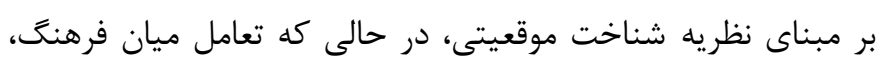

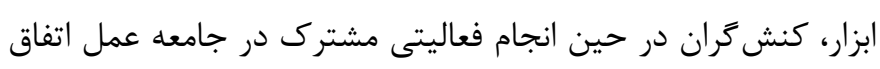

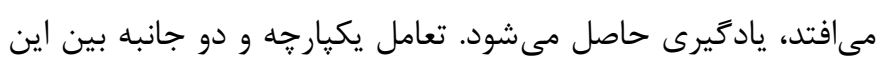

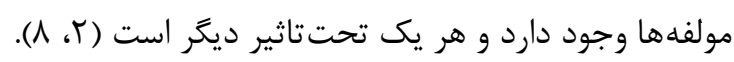

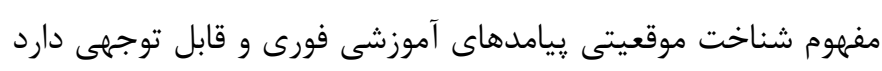

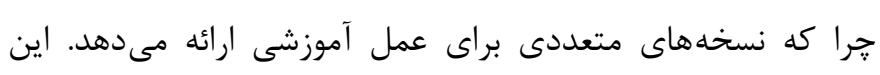

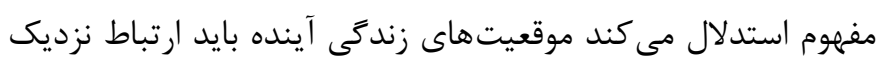

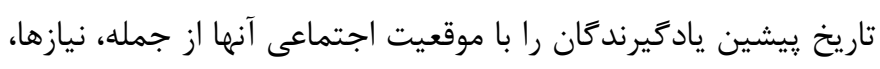

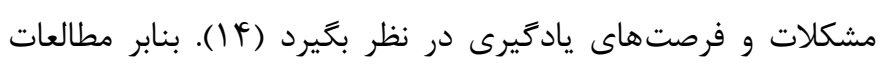

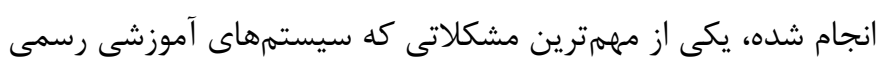

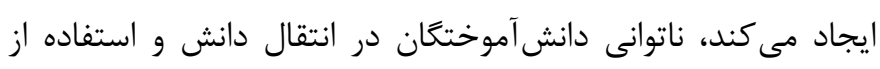

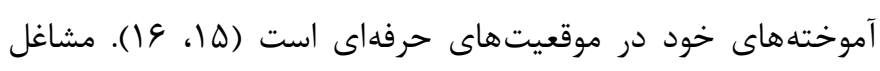

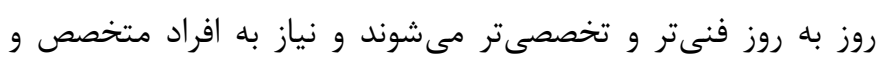

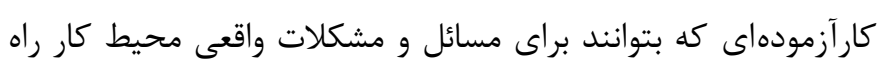
حلى ارايه دهند، افزايش مى يابد. اما، در اغلب موارد دانش آموختخان

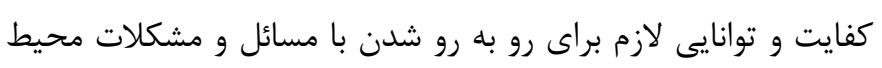

كار را در خود نمىيابند (IV)

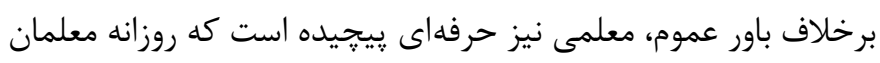

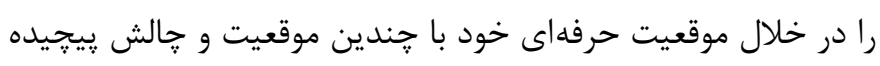

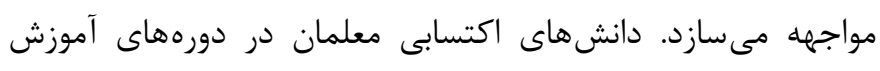

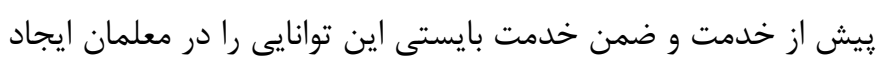

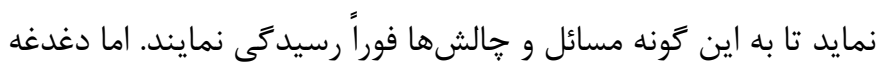

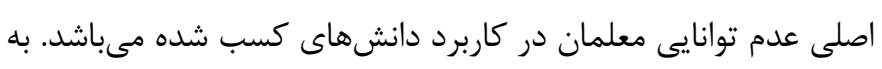

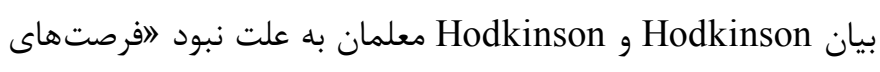

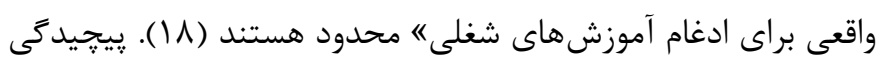

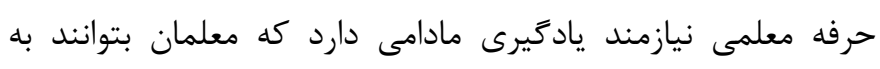

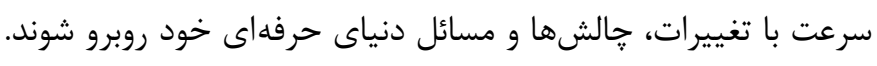
نكرانى اصلى نظريه شناخت موقعيتى نيز همين است، به اعتقاد آنان 
بافته ها

تبيين مولفه هاى برنامه درسى تربيت معلم

هدف

نظريه شناخت موقعيتى دانش را محصولى يويا از روابط منحصر به فرد بين فرد و محيط مىداند؛ بنابراين يادگيرى، محصول طبيعى از تعامل افراد در زمينهايى است كه در آن دانش به طور طبيعى تعبيه شده

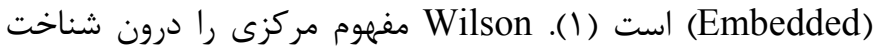
موقعيتى خلاصه كرده و مى كويد: الانش و يادگيرى بايد يكيارجه

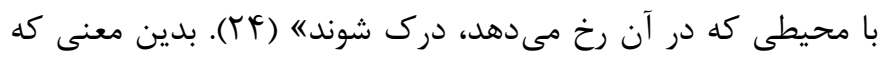

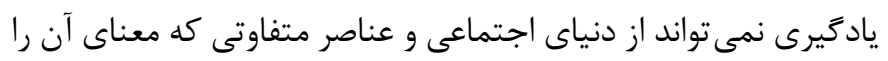
در بر مى گيرد، جدا شود. به نظر مىرسد كه دانش و مهارت شناختى بسيار به زمينه اكتساب آن وابسته است. كليدى ترين هدف از منظر نظريه يردازان در اين حوزه، انتقال دانش بان كاربردى و مستحكم به فراگيران است. وابستگى دانش يا مهارت به عوامل موقعيتى نظير جو اجتماعى، ويزگى ها و مشخصه هاى فيزيكى و ميانجى گرى عوامل موجود در زمينه، روشن كننده اين امر خواهد بود

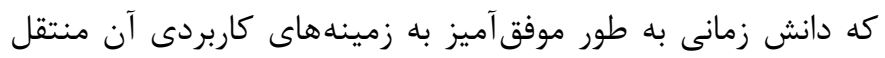

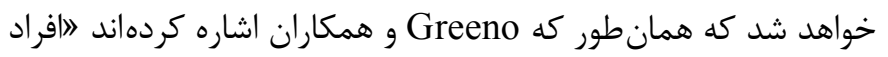

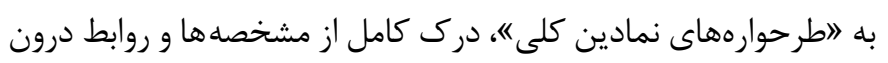

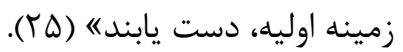

در معمارى كلان برنامه درسى تربيت معلم ايران 》آشنايى با دانش و فهم اصول و روشهاى كاربست دانش در موقعيتهاى مختلف تربيتى و كسب توانايىهاى موقعيت شناسى" از شايستخى هاى كليدى دانشجو_معلمان ياد شده است (ع)). بنابراين حرفه معلمى نيازمند دانش و مهارتى است كه در موقعيت ويزه آن مورد كاربرد

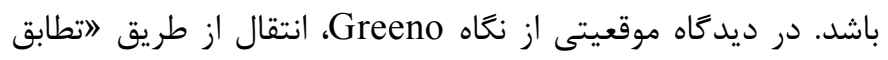

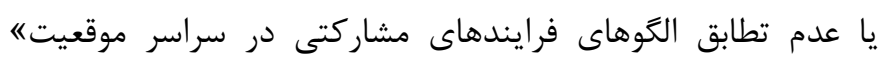

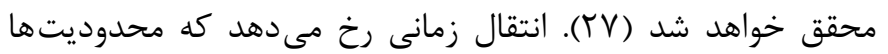

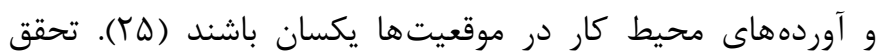
هدف 》انتقال دانش كاربردى و مستحكم" زمانى محقق خواهد شد كه فرصتى فراهم شود تا دانشجو_معلمان به طور مداوم از طريق تجربه و مشاهدات در موقعيتهاى معتبر، دانش و مهارت عملى رات المات

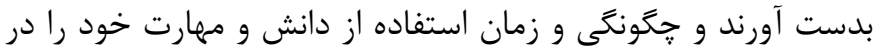
اين زمينهها را درك كنند. در حالى كه دانشجو_معلمان به ندرت به موقعيتهاى معتبر معلمى دسترسى دارند، حتى تحت شرايط

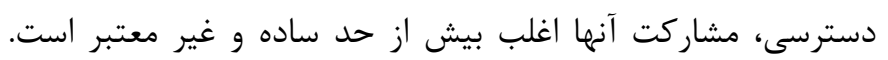

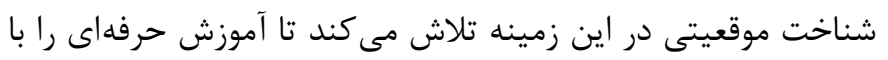

امكاناتى در زمينه رشد شناختى، فرهنكى و اجتماعى، راهنمايى خواهد بود تا تربيت افرادى حرفهاى، عمل گرا، فكور، توانمند در محيطهاى اجتماعى و شغلى را تسهيل مى كند.

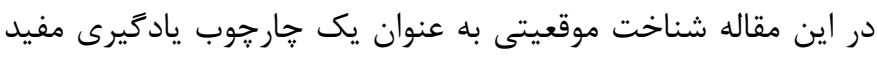
براى تسهيل و توسعه تربيت معلم ريشنهاد شده است. نظريه شناخت

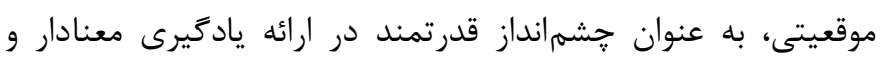

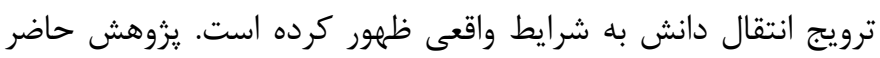
با نحاهى به نظريه شناخت موقعيتى؛ ديدكاهى كه تربيت را به معناى جامعهيذيرى تازهواردان در بسترى از فعاليتهاى كارى در حال انجام مى داند ( آY)؛ درصدد تبيين و طراحى جار جوب مفهومى برنامه درسى تربيت معلم است. خار جوب مفهومى بر جهار مولفه اصلى تمركز دارد: هدف، فرصت هاى يادَيرى، راهبردهاى يادَيرى و ارزيابى.

\section{روش كار}

طراحى الكوى مفهومى، با استفاده از روش يزوهش نظريهاى انجام شد. هدف يزوهش نظريهاى در برنامه درسى خلق و نقد طرحوارههاى (مدل يا جار جوبهاى) مفهومى است كه ماهيت بنيادى و ساختارى يديده ها و فرايندهاى برنامه درسى را قابل فههم مى كند. طرحواره مفهومى، بهى

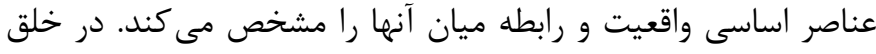
آنها معمولاً دو مفهوم تصريح مىشوند: مفاهيم اساسى و مفاهيم ساختارى. عناصر يا مؤلفههاى كه آنها را سازنده واقعيت مى دانيم، در مقام مفاهيم اساسى و روابط شناسايى شده ميان اين عناصر به عنوان مفاهيم ساختارى شناخته و تعريف مى شوند. مجموعه كلى اين

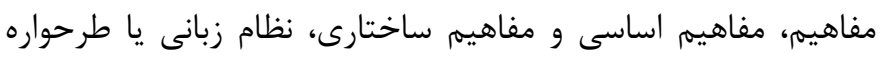

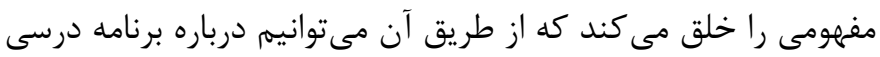
بينديشيم و بحث كنيه. در واقع طرحوارههاى مفهومى به دنبال تبيين ماهيت اساسى يديدههاى برنامه درسى هستند. طرحوارههاى مفهومى لرى در هيج شاخهاى از تفكر و عمل مفروض نيستند؛ بلكه بايد آن را خلق كرد (YT). از اغلب مدل هاى مفهومى در يزوهشهاى آموزشى

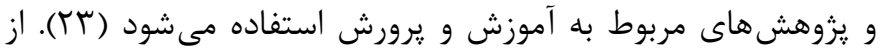
اين رو، براى طراحى جهار جوب مفهومى سعى شد با شناسايى مفاهيم

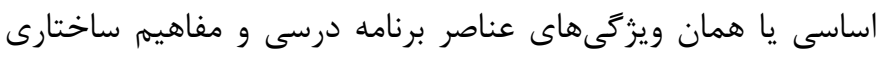
كه در واقع همان شناسايى ارتباط بين اين عناصر مىباشد، از طريق

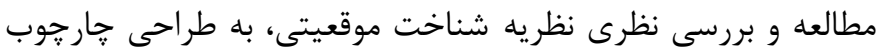
مفهومى برنامه درسى تربيت معلم دست يافته شود. در اين يزوهش، جهار مولفه مشترك مورد تاييد اغلب نظريه يردازان حوزه جارجوب تربه و الكَى برنامه درسى با تكيه بر نظريه شناخت موقعيتى تبيين شد. 
توانمندسازى در زمينهاى معتبر در مقابل زمينههاى نهادينهسازى

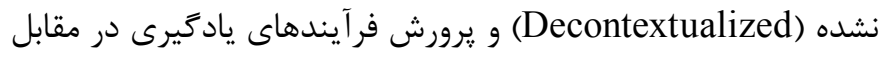
نتايج يادگيرى است. بر مبناى اين ديدكاه تربيت معلم بايستى به

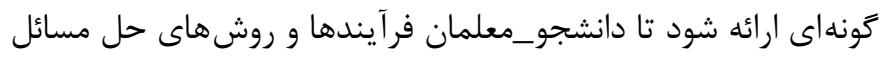

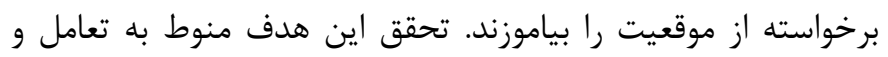

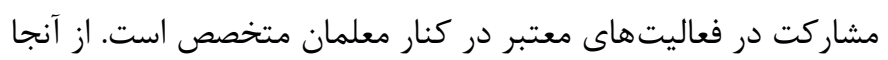

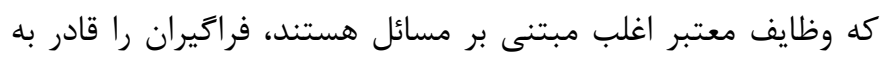

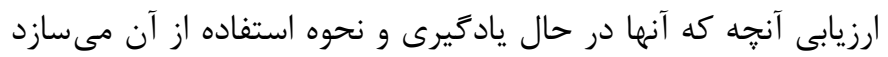

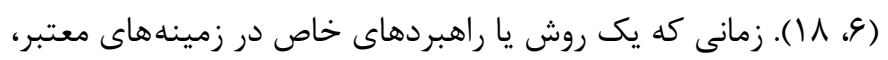
به جاى مفهوم، ارائه شود، آنها بر اساس تجربه دست اول ياد مئ كيرند. Harley

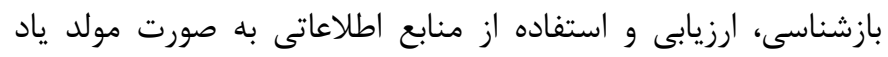

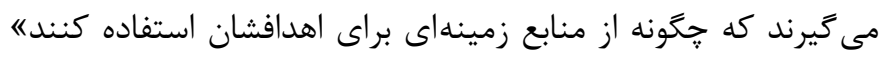

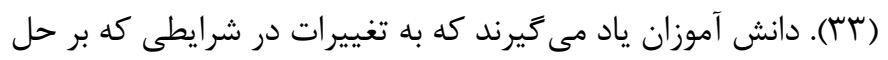

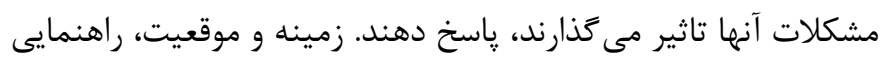

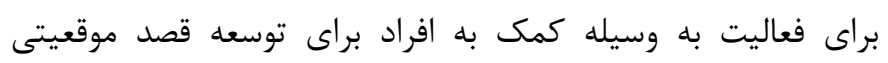
فراهم مى كند. (Situational intent) در نهايت شكل دهى هويت حرفهاى فراگيران از اهداف مهمى كه از نظريه شناخت موقعيتى قابل برداشت است. فرايندهاى تفكر، كنش و

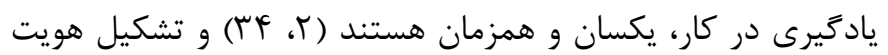
و ذهنيت هاى شغلى و يادگيرى را شامل مىشوند (ه). هويت و تحول

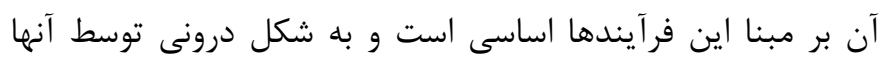

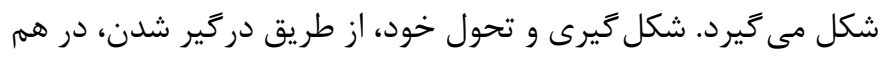

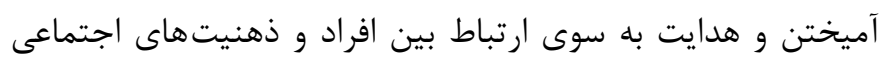

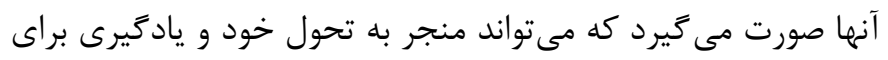

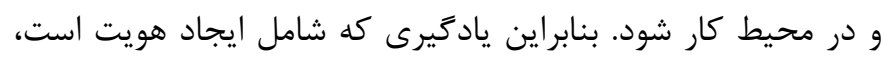

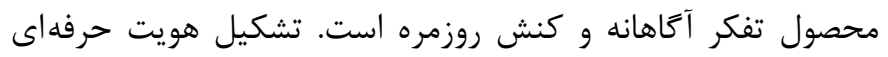
دانشجو_معلمان نيز همانطور كه Billett اشاره كرده است ملزم به مشاركت در محيط كار و شناسايى احساس افراد از هويت خود دارد كه هر دو به واسطه كنش و هدفمندى شكل مى دهند و شكل مى يابند (هऍ). از آنجا كه رابطهاى نزديك و در عين حال وابسته

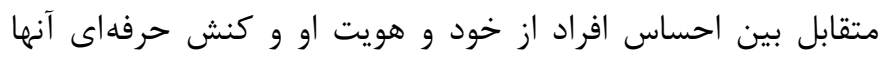

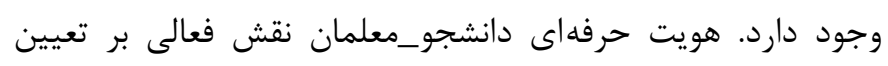

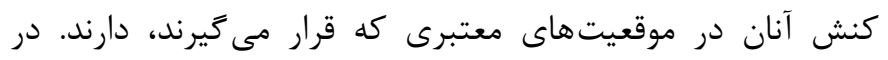

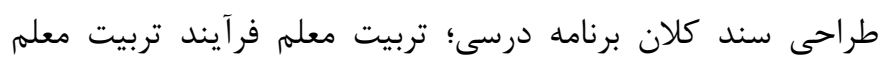

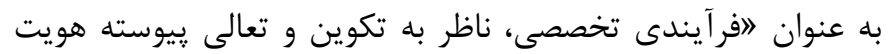

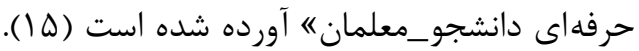

تأكيد بر دانش و مهارت در زمينههاى واقعبينانه، انتقال دهد. در اين راستا نظريه شناخت موقعيتى به بيان Choi و Hannafin، وظايف

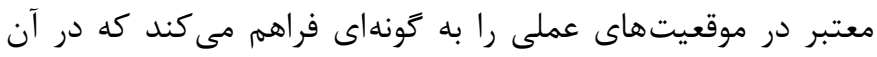

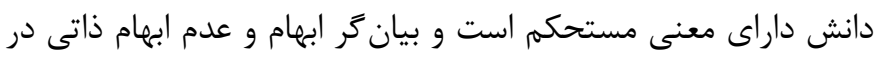

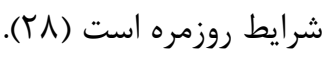

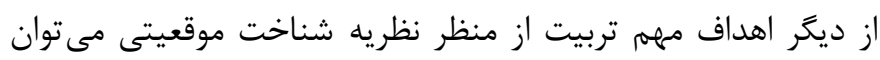

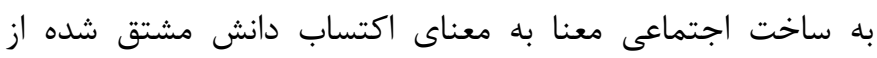

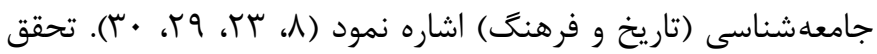
هدف "اساخت معنا در درون جامعه عمل"، دستيابى به درك مشترك و توانايى انجام فعاليتهاى حرفهاى مطابق با همكاران با تجربه و شرايط مورد نياز محيط كار را ممكن مىسازد (آس). در واقع درك از باورها،

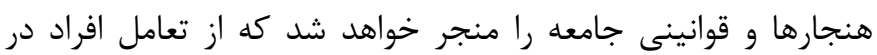

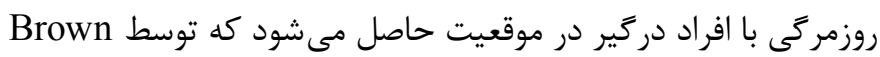

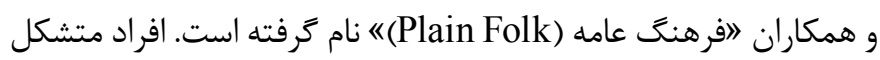
دهنده 》فرهنگ عامه" كه در يك موقعيت دخيل هستند، يك فعاليت خاص را مشروعيت مى بخشند. اين برداشت بر جامعه حرفهاى معلمان

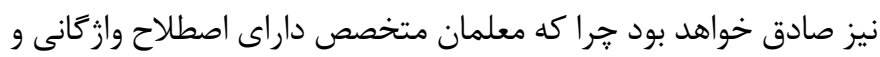
رفتار خاص خود هستند كه با ساير عناصر فردى جامعه مثل والدين و دانشجو_معلمان متفاوت است. در مواجه با مسائل برخاسته از موقعيت،

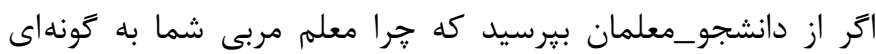
خاص در مقابل رفتار خاطى دانش آموز در كلاس درس برخورد كرده آندان

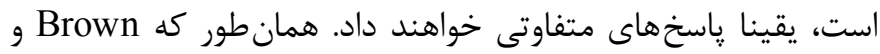

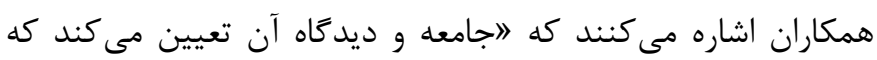

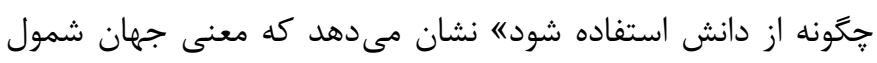

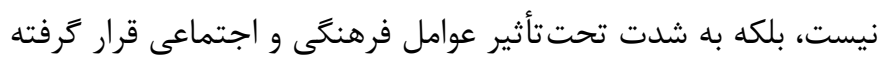

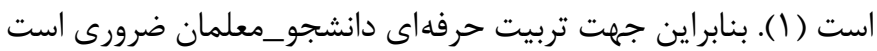
كه دانشجو_معلمان با فرهنگ عامه معلمان متخصص در به كاركيرى دانش آشنايى يابند تا به دانش نظرى داراى مبناهاى اجتماعى و فرهنكى دست يابند كه به ساخت اجتماعى معناى آن كمك مى كند.

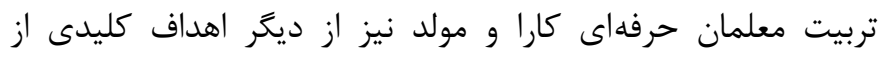
ديدَاه نظريه شاخت موقعيتى است. از منظر اين نظريه، كارشناسان

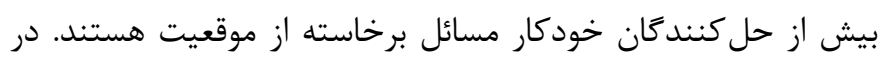

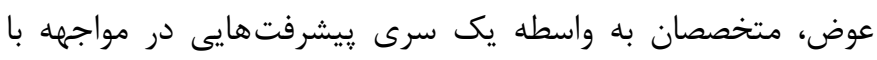

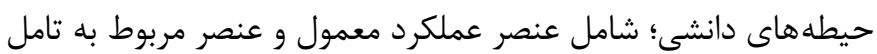
و مشورت است، متخصص مى شوند. اين فرايند متخصص شدن توسط Sereiter Scardamalia برنامه درسى نظريه شناخت موقعيتى تاكيد بر فراهم آوردن تجربيات 
است كه سيستمهاى فعاليتى بخشى از طراحى برنامه تربيت معلم را در فرصت هاى يادگيرى بر بخيرد. سيستم فعاليتى در بركيرنده افراد، جوامع عمل، مصنوعات،

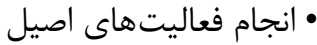
ابزارها و فرهنگ، قوانين، هنجارها و باورها، تاريخ، سطوح مقياس،

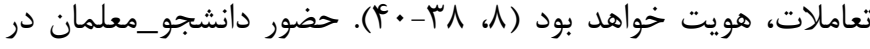
سيستمهاى فعاليتى اهميت دارد. با حضور در سيستمهاى فعاليتى

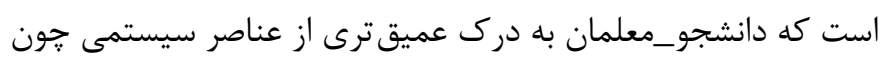
باورها، قوانين، سطوح و ابزارها و مصنوعات فرهنكى دست مى يابند و با دنيايى كه كنشهاى حرفهاى تدريس صورت مى

زبان؛ ميانجى فرهنَ است. زمانى كه يادگيرى را نتيجه تعامل ميان

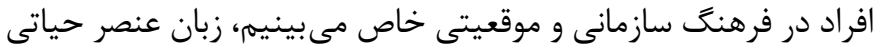
در فرآيند يادكيرى محسوب مى شود. افراد با استفاده از زبان، باورها، فرهنَ و تاريخجههاى شخصى و جمعى را در قالب كفتمان انتقال

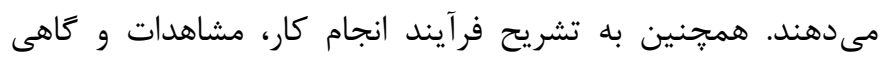
تشريح توضيحات تئورى مى يردازند كه موجب فهمم درست و متقابل از مفاهيم، كنشها و فعاليتها خواهد شد (T). Compton در مقاله خود يِيشنهاد مى كند كه افراد ايدهاى خود را در مورد اصطلاحات ناسازگار، به اشتراك بكذارند. جرا كه مكالمات مربوط به مشكلات خاص و موقعيتهاى خاص، تفاوتهاى اداراكى و كنشى مربوط به آن موقعيتها را روشن مىسازد و توافق را منجر مى شود. هر جه موقعيتها عينى تر باشد، امكان حصول به توافق راحت تر خواهد بود. (أl). بنابراين كفتمان فرصتى بيشتر براى تبادل افكار و ايدهها

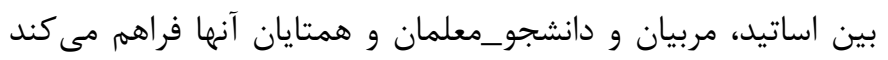
(Y-1). تعاملات ميان كنش كران برنامه درسى تربيت معلم كه كَفتمان عنصر كليدى آن خواهد بود، انتقال دانش حرفهاى و كاربردى را ممكن خواهد كرد. دانشى كه عوامل اجتماعى و فرهنكى موقعيت و يا به بيان ديكر با عناصر موجود در سيستم فعاليتى عجين شده است.

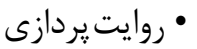
تامل در مفاهيم، دانش و كنشهاى موقعيتى محدود به تعاملات و رودائ ارتباطات جمعى نخواهد بود. يك محيط يادگيرى مبتنى بر شناخت

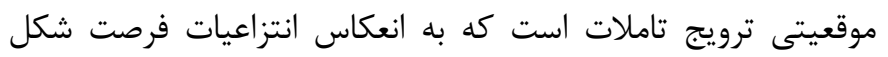

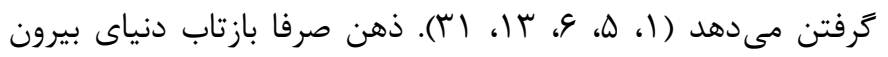
نخواهد بود، بلكه تفكر افراد جايگاهى است براى برقرارى ارتباط بين

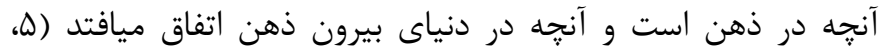
^). محيط يادگيرى مبتنى بر شناخت موقعيتى بايد فرصتى را براى دانشجو_معلمان فراهم نمايد كه صرفا دريافت كننده ساختارهاى ذهنى 
بود. در اين راستا، بِيشنهاد مىشود از دانشجو_معلمان خواسته شود

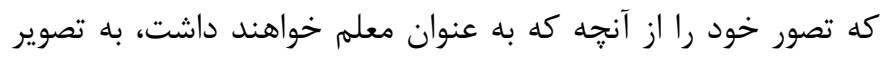

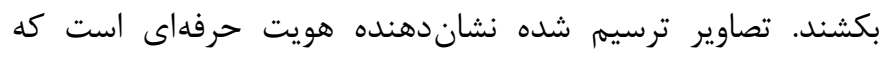

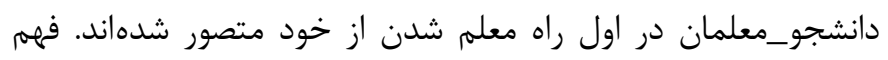

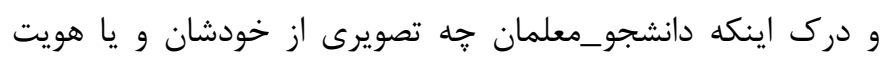

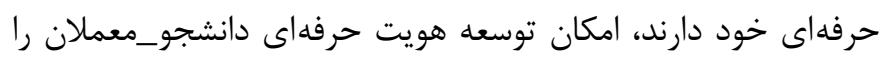
تسمهيل مى بخشد.

\section{راهبردهاى ياددهى يادكيرى}

دو مفهوم كليدى محوريت اين نظريه را بر خود دارد: كارورزى شناختى ياديرى (Cognitive Apprenticeship) استفاده از مدل شناختى كارورزى در حال حاضر در رابطه با آموزش و

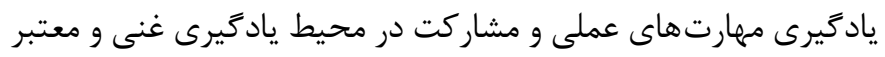
و تعامل با جوامع توصيف شده است.

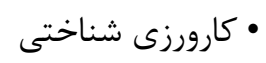

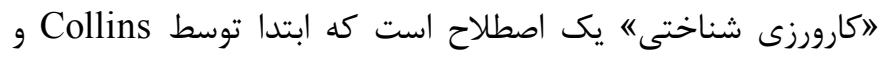

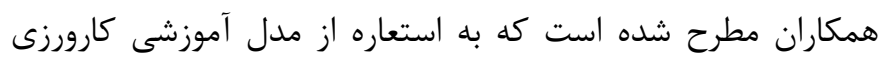

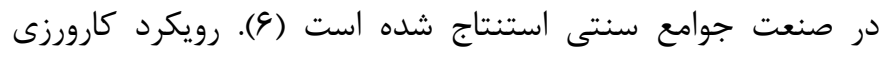

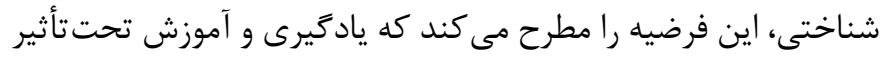
فرايندهاى اجتماعى شامل مشاركت فعال در محيطها و فعاليتهاى

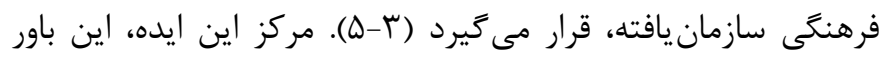

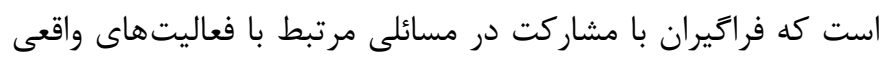
در حين تعامل با كارشناسان درك مفهومى خود را توسعه مى دهند

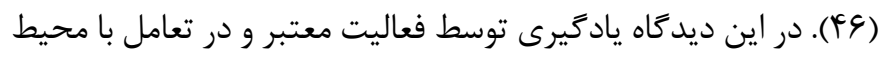

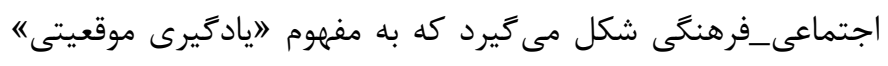

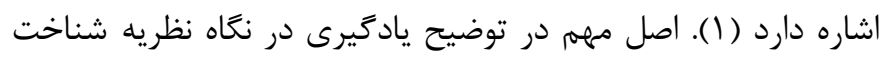

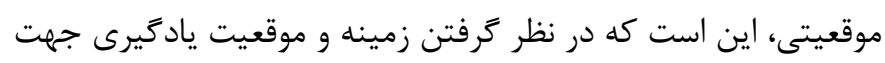

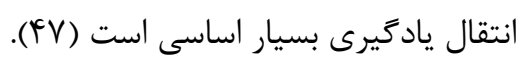

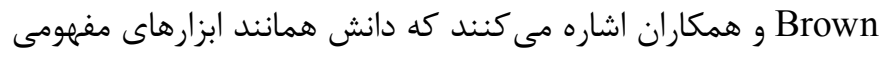

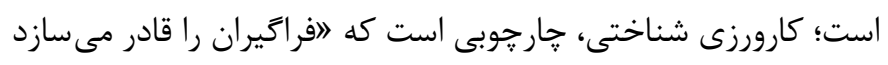
تا ابزارهاى مفهومى را در فعاليت معتبر و در موقعيت حقيقى به به دست آنست

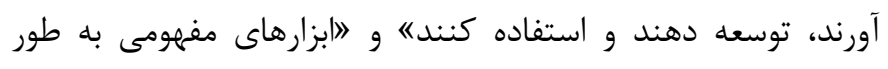
مشابه، خرد جمعى فرهنگ موقعيتى كه مورد استفاده قرار مى گيرد

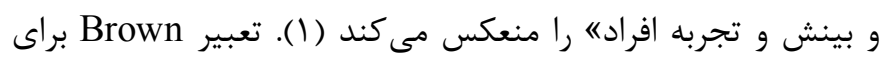

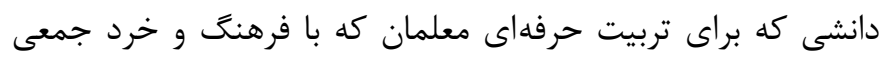

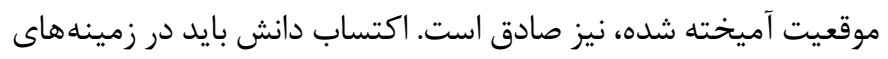

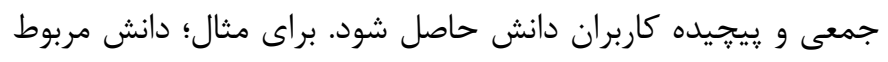

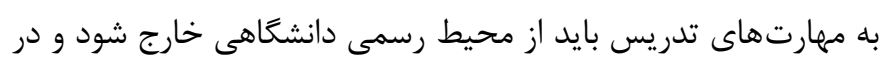

و معنايى كنش گران دركير در موقعيت و جوامع عمل نباشند، بلكه

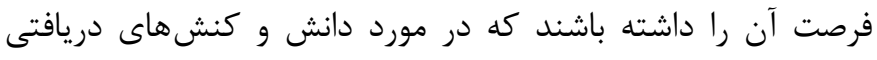

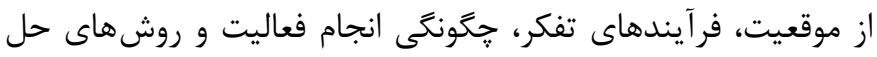

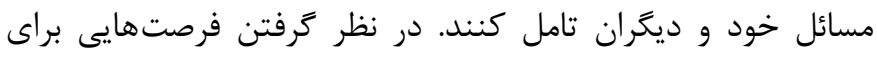

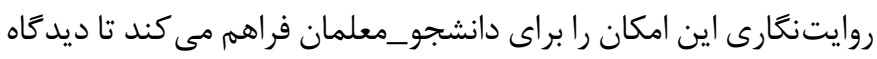

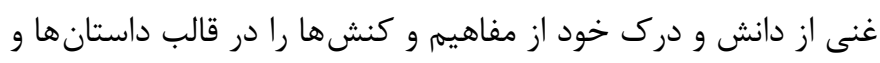

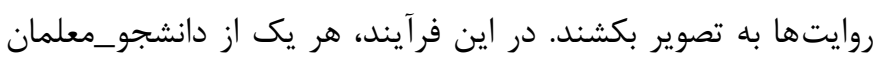

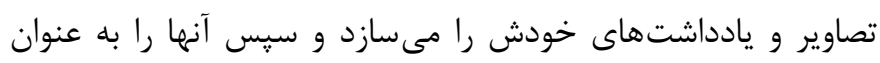

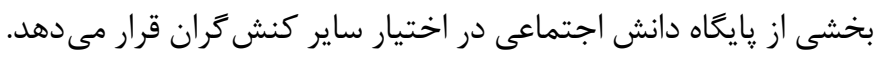

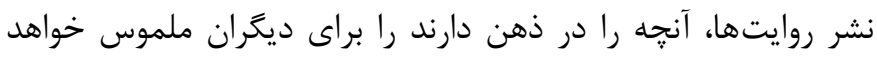

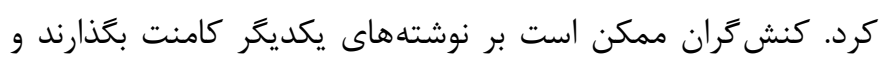

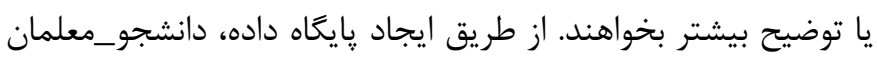

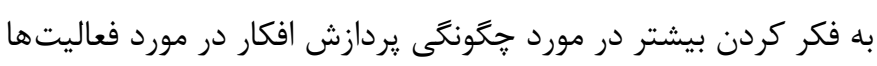
وكنش ها تشويق مى شوند.

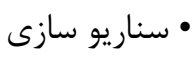
در طراحى كارورزى تربيت معلم ايران، آمادهازى حرفهاى دانشجوـ

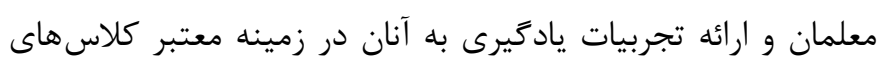
درس در طول دو سال دوم دوره تربيت معلمى ارائه مى شود. اين برنامه دئه

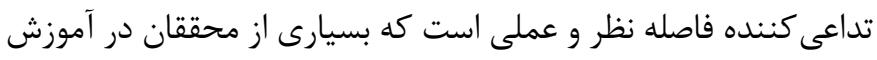

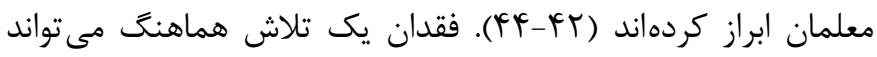

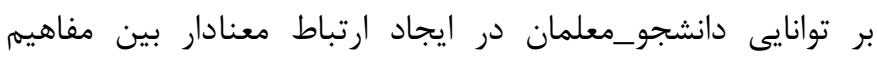

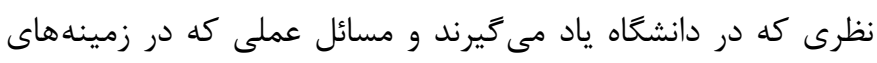

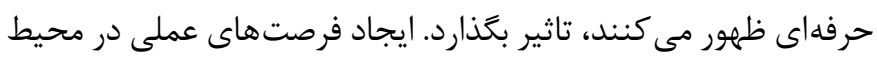
آكادميك شامل سناريوسازى و تدريس هاى خرد (Microteaching) به كاهش شكاف نظر و عمل و تربيت معلمان حرفهاى كمك خواهد

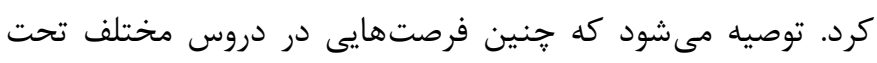
عنوان راهبردهاى يادكيرى ارائه شود.

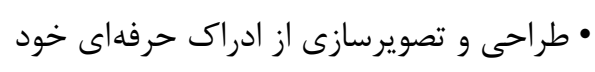

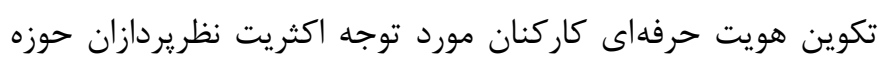

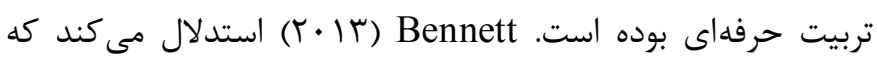

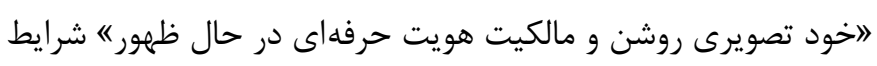

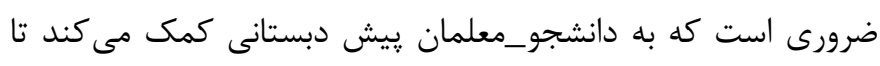

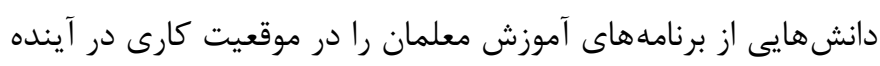

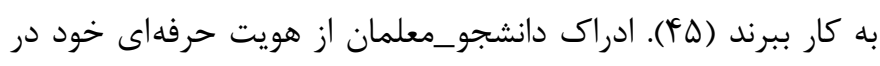

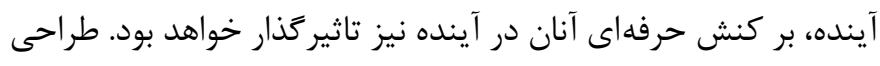

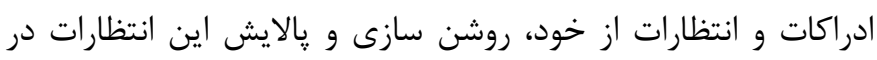

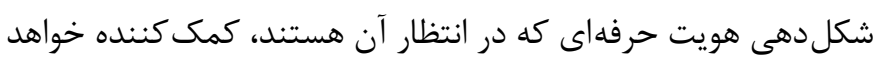


فيلمهايى در محيط كلاس يا به صورت فردى در خارج از كلاس حاصل شود. همجنين رسانه فرصتى براى يادگيرندگان فراهم مى كند كه دسترسى به مواد آموزشى در زمان، مكان مناسبترى صورت گيرد. بهره كيرى از تكنولوزى و رسانه با ايجاد كارورزى منعطفتر و كستردهتر،

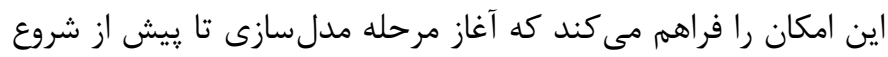

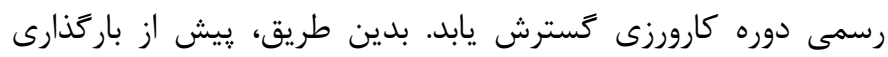

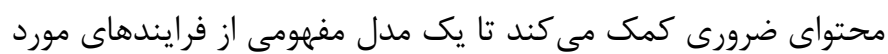
نياز را ايجاد كنند و يك مرجع براى فعاليتها و كنشهايى كه مىتوانند

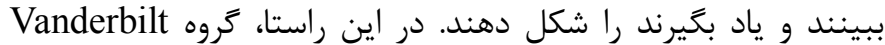
آموزش لنكر كاهى (Anchored instruction) را توصيه مى كند، كه از شبيه سازى هاى ويدئويى بهره مى خيرند. حوادث يا مشكلات واقعى دنياى واقعى از طريق اين رسانه معرفى مىشود تا بتواند يادگيرى بعدى را به وجود آورد. اين ممكن است براى دانشجو_معلمان كاملا متناسب باشد:

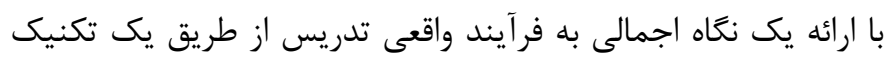

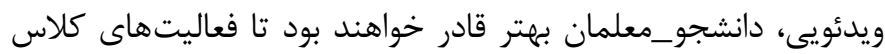

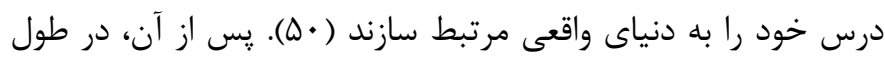

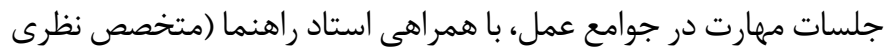
و عملى) معلم/متخصص مهارتها معرفى مىشوند و فرآيند مشاركت همراه با دادن توضيحات و دلايل انجام به اين روش تشريح مىشود. ارائه اين فرصت به جوامع عمل مههم است؛ جرا كه فرصت آشكارسازى و بحث در مورد دانش ضمنى را فراهم مى كند تا توسعه فرايندهاى شناختى

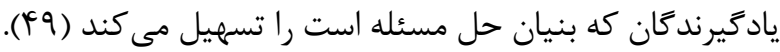

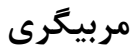
در طى مرحله بعد، يادَّيرندًان سعى مى كنند مسائل برآمده از موقعيت

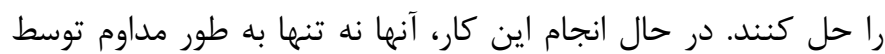
متخصص مشاهده، بلكه "امنتور (Mentor)" شوند (1)). در مرحله مربيگرى، فرصتى براى يادگيرندگان فراهم مىشود تا به كنش حرفهاى زير نظر متخصصان بيردازند و تصميمَيرى در مورد مسئله هاى بر آمده از موقعيت را تجربه كنند. Billett از اين فرصت به عنوان مشاركت هدايت شده نام برده است كه فرصتى براى مشاهده و يادكيرى

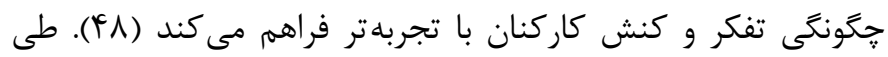
مرحله مربيكرى، فرصتى فراهم شود تا دانشجو_معلمان در محيطهاى

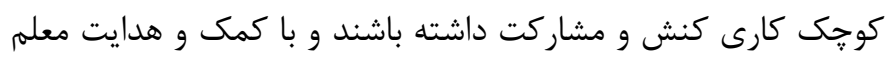
متخصص به تدريس مشغول شوند. در عين حال، معلم متخصص به عنوان يك مربى، راهنمايى ها و هدايتهاى ظريف را به شكل نكات،

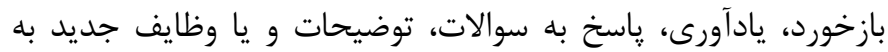

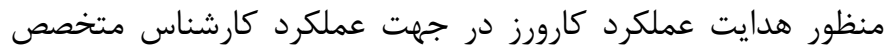

محيط كاربردى مدرسه و در ميان كاربران آن آموخته شود. اين مبحث طراحى و ايجاد كارآموزشى شناختى را ضرورى مى كند. در اين يزوهش كارآورزى شناختى طى جهار مرحله شامل مشاهده و مدلسازى، مربيخرى، داربستزنى و محو شدن و استقلال در انجام

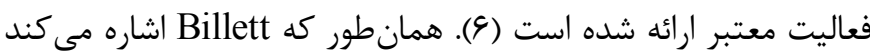

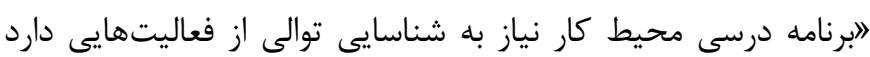

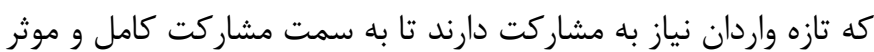
بيشرفت كنند). در اين توالى، فعاليتهاى محيط كار (مشاغل، وظايف و تعاملات) به عنوان مسيرى براى تازمواردان در نظر ترفته مىشود كه در ابتدا الزامات كار و محيط كار را درك نمايند، و سيس به به تدريج ظرفيتهاى مورد نياز براى اجراى اين الزامات را توسعه دهند (مثا). اين رويكرد، اهميت سطح مشاركت دانشجو_معلمان را نشان مىدهد. مشاركت دانشجو_معلمان بايد از وظايف يِيرامونى مشروع همانند حضور در كلاس هاى درس جهت تا مشار كت كامل همانند تدريس مستقل فراهم شود (T). بدين گونه، طى فر آيند كارورزى شناختى، با انجام فعاليتهاى

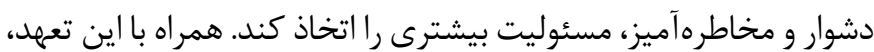
حس هويت معلمى را در تعامل با ساير كنش گران نظير مربى متخصص

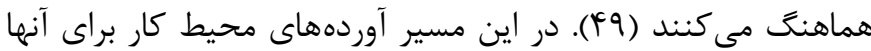
فراهم مىشود و آنها مشاركت آكاهانه و فعالانه خواهند داشت.

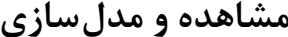

مدلسازى، سنَ بناى كارورزى شناختى است كه فرد به مشاهده و

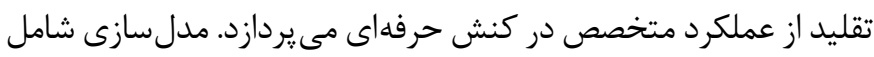
نشان دادن نحوه انجام كار توسط متخصص است تا فراگيران بتوانند

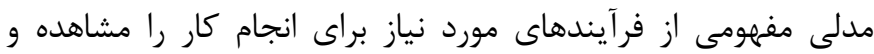
بسازند. در حوزههاى شناختى، اين امر مستلزم برونىسازى فرآيندهاى

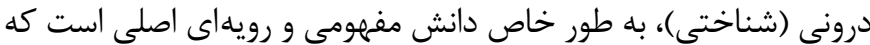
متخصصان استفاده مى كنند (9). بدين ترتيب معلمان يا مربيان، دانش ضمنى خود را با مدل سازى راهبردها براى يادكيرندكان در فعاليت معتبر

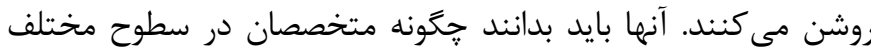
رفتار و كَتتكو مى كنند تا دريابند كه جَكونه تخصص در كَفتمان و ساير

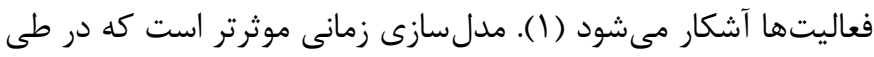

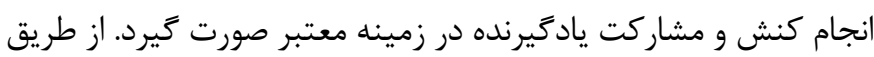

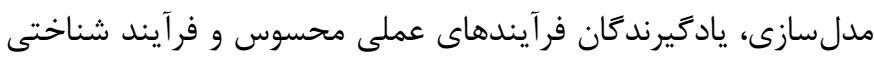

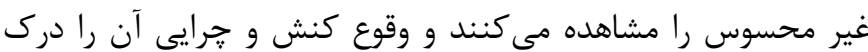

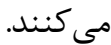

در مرحله مدلسازى دانشجو_معلمان عملكرد متخصص را مشاهده مى كنند. اين مرحله مىتواند با حضور كارورز در محيط كار و مشاده 
مى كند كه تازهوارد بتواند به طور مستقل عمل كند (UT). در همين راستا، معلمان متخصص در دورههاى كارورزى در انجام بخش هايى از وظايف و فعاليتها كه دانشجو_معلمان هنوز نمىتواند به تنهايى مديريت كند، داربست ارائه مى كند. الزامات انجام اين بخش، تشخيص دقيق دشوارى يا سطح مهارت آنها در انجام فعاليت است. تصميمى گيرى در مورد توانايى و مهارت دانشجو_معلمان بر مبناى مشاهده عملكرد دانشجو_معلمان و

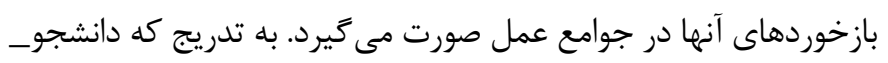
معلمان توانايى و مهارت لازم را در تدريس مستقل كسب كنند، حمايت معلمان متخصص به عنوان مربى آنها كاهش و حذف مى شود. • جوامع عمل ملمان منصص "جوامع عمل "ايدهاى شناخته شده از نظريه شناخت موقعيتى است

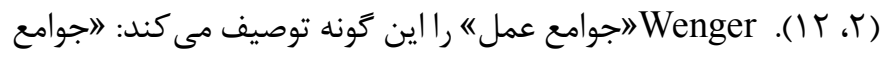
عمل، گروهى از افرادى هستند كه نخرانى، مسئله و اشتياق مشتركى در مورد موضوعى مشترك دارند و دانش و تخصص خود را در اين زمينه با تعامل با يكديخر عمق مىبخشنده (سH). در تئورى جوامع عمل استدلال مى شود كه افراد از طريق مشاركت فعال و درگير شدن با ديخران در فعاليتهاى فرهنكى در جوامع اجتماعى خاص مانند يك

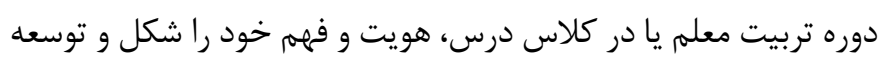

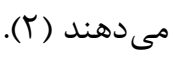
بنابراين بودن و مشاركت داشتن در جوامع عمل و تعهد داشتن به حيطه و موضوعى خاص؛ دو شرط اصلى براى مفهوم جوامع عمل

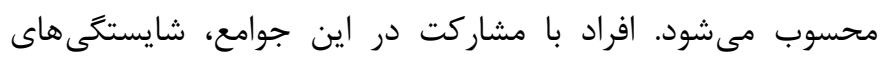
منطبق با زمينه و موقعيت خاص را در مى يابند. جوامع عمل در تعاملى همخرا بين شايستخى و تجربه همراه با مشاركت متقابل، رشد مى كند ميند. اين جوامع فرصتى فراهم مى كند تا در مورد شايستكى از طريق تجربه

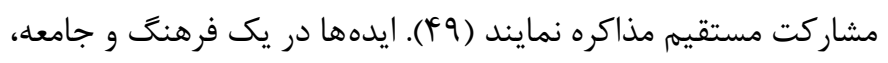
مبادله و اصلاح مىشوند و سيستمهاى اعتقادى به وسيله كفتمان و روايتها گسترش مىيابند (1). تعامل اجتماعى و درون زروهى و مكالمه، باورهاى افراد را به صورت حرفهاى ايجاد و تعديل مى كنند (DF) شناختى است؛ تعامل گروهى براى يادگيرى ضرورى است.

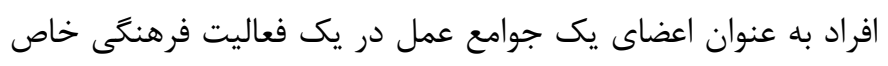
در طول زمان شركت و سهيمى مى شوند، درك خود را در مورد اينكه جه كسى هستند و جه جيزى در مورد جوامع و اهدافشان مى دانند، توسعه مى دهند. طبق كفته Wenger، كاربرديذيرى جوامع عمل بر تربيت معلم، يادگيرى محيط كار را به عنوان يك فعاليت اجتماعى مدوام به

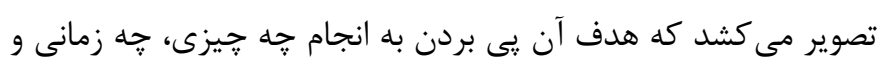

ارائه مى دهد (9). در اين فرصتها متخصص به عنوان مربى، به بررسى اين موضوع مى يردازد كه آيا افراد به شيوهاى مناسب عمل مى كنند؟؛ در اين راستا از آنها مى يرسند كه جِّونه كنشى در وضعيت خاص خواهند داشت، جراو جَّونه تلاش خواهند كرد تا بهترين نتيجه حصول شود؟ يرسيدن اين سوال ها كمك مى كند كه در مورد دانش، مهارت ها و راهبردهاى خود استدلال و تامل داشته باشند و بر كنشهاى خدى خود كنترل بيشترى داشته باشند ( آ⿱). راهنمايى و هدايت به صورت ضمنى و در صورت نياز كارورزان فراهم مىشود. مربى اشتباهات، تصورات غلط و يا استدلال معيوب را در تفكر يادگيرندگان را شناسايى و به تصحيح آنها كمك مى كند. بدين طريق مربى، دانشجو_معلمانى را كه روش يا عملكرد ضعيف را به دليل ناديده گرفتن بيشنههادات و اصول و سوتفاهمات دارند را شناسايى مى كند. همجنين دانشجو_معلمان در قالب جوامع عمل، شامل گروهى از كنش گران است كه سهمه اجتماعى ايدهها و درى مورد نياز در مورد وظايف و فعاليتهاى در حال انجام را دارند، ادراكات، برداشتها و تجربيات خود را بررسى مى كنند. استفاده

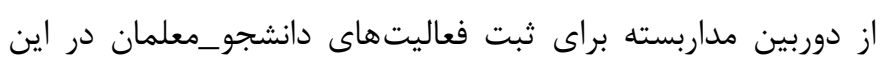
مرحله، مبناى بازتاب و بحث را فراهم مى آورد. ماهيت مكانهاى دراي دوربين و ييكربندى كنترل آنها به اين معنى است كه همان عملكرد را مى توان همزمان با استفاده از دوربين هاى جند ديد كاههاى مختلفى از يك فعاليت مشابه ارائه مى شود (YV)

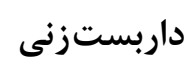
داربستزنى بر "منطقه تقريبى رشد《 Vygotsky استوار است كه تازهوارد تحت حمايت و يشتيبانى متخصص كنش مى كند. بر طبق بقريق مفهوم لامنطقه تقريبى رشده، توانايى و سرعت يادگيرى افراد تاثيرى

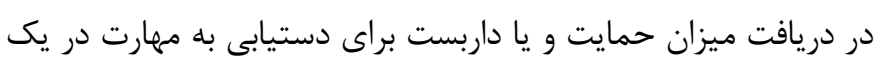

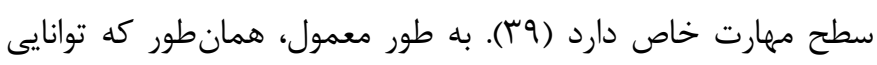
فرد بهبود مى يابد، حمايت مستقيم مىتواند به تدريج برداشته شود يا از بين برود. با اين حال، فرد در زمينههاى مختلف، مجددا نياز به حمايد مايت

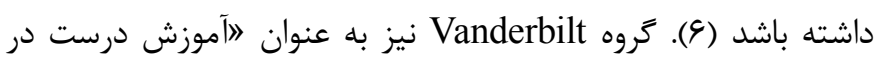

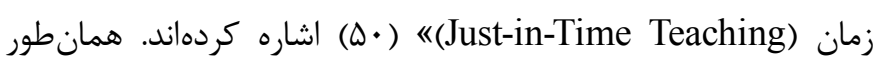
كه فراخيران صلاحيت بيشترى كسب مى كنند و اعتماد بيشترى به

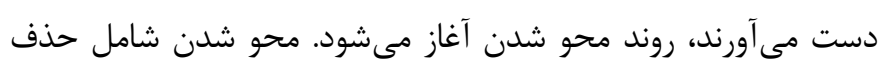
تدريجى حمايت از زمانى كه فراخيران به طور فزايندهاى استقلال خود

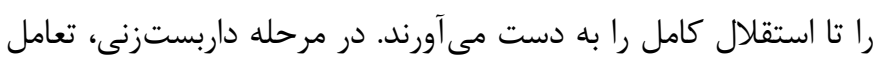
بين تازهوارد و كارشناس، ارتباطاتى را سازماندهى مى كند تا تازهوارد به درك كامل از وظايف دست يابد. كارشناس همان طور كه توانايى هاى كارورز را بهبود مىبخشد، حمايت و يشتيبانى خود را تا جايى تعديل 
باشند و از يك جامعه به يك ديگر به سهولت منتقل شوند و در حركت باشند. اين فرصت حركت و جابه جايى در جوامع مختلف، امكان انتقال دانش به موقعيت هاى متفاوت را ممكن مى سازد. مفهوم جامعه عمل و كارورزى مفاهيم ييوسته و نامتمايزى است كه هر يك به ديخرى نيازمند است. بنابراين اين فرصتهاى ياددهى و ياد گيرى به گونهاى صورت مى گيرد كه نيمى از برنامه به كارورزى

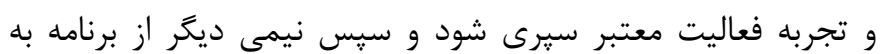
كفتمان با اعضاى جوامع عمل در مورد تجربيات يرداخته شود. فرآيند در كل برنامه يكسان است: مشاركت در مراحل كارورزى و كفتمان با اعضاى جوامع عمل. حركت و رفت آمد از هر يك از مراحل به جوامع عمل و سيس بازگشت به فرصتهاى تجربه كارورزى، تشكيل دهنده حلقههاى فر آيند يادگيرى خواهند بود. شكل r نشاندهنده مدل تجويزى براى كارورزى برنامه درسى تربيت معلم است كه در اين يزوهش ذيل عنوان "راهبردهاى ياددهى يادكيرى" برنامه درسى آورده شده است. اين مدل با مطالعه و بررسى ديدكاه نظريه يردازان شناخت موقعيتى افرادى جون Brown

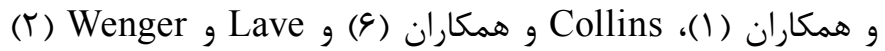
استنتاج شده است. اين راهبرد در قالب دو مفهوم كليدى در نظريه شناخت موقعيت_كارورزى شناختى و جوامع عمل_فرصتى براى يادگيرى در زمينه فراهم مى كند. بر طبق اين مدل، دانشجو_معلمان از مشاركت يِيرامونى مشروع به سوى مركز كه انجام مستقلانه فعاليت است، حركت مى كنند. طى اين حركت از مرحله مشاهده و مدل سازى، مربيگرى، داربستزنى به استقلال و محو شدن دائما در تعامل با جوامع عمل قرار مى گيرند، شناخت، دانش، مهارت و ارزش هاى دريافت شده را تعديل و تثبيت مى كنند.
جَكونكى منطبق با رويdهاى خاص است. اعضاى جوامع عمل در تحقق اين هدف نقش دارند. اين جوامع مىتواند گروهى از دانشجو_معلمان، متخصصان، اساتيد دانشگاهى و كاركنان مدرسه باشند. در خلال جوامع عمل، دانشجو_معلمان به عنوان عضوى از جامعه مشاركت واقعى خواهند داشت و به تبادل ايدها و معانى با ساير كنش گران خواهند يرداخت. ارتباط در اين جوامع سلسله مراتبى نيست. بلكه، به شبكهاى از روابط پييجيده و دو طرفه بين كارورزان و ساير اعضا اشاره مى كنند. بنابراين هر يك از اعضاى جوامع عمل بايستى قادر باشند كه نظرها، نكرش ها و ديدكاهها خود را در مورد فعاليتها و كنش هاى حرفهاى اظهار كنند و توسط ساير اعضاى جوامع عمل مورد تحليل، نقد و انعكاس قرار دهند. تعامل متقابل سبب مىشود كه افراد به تصحيح، ״الايش و بازنخرى دانش و تجارب دريافتى از موقعيت بيردازند (هذ). بر مبناى نظريه شناخت موقعيتى حضور يك يا جندين جوامع عمل

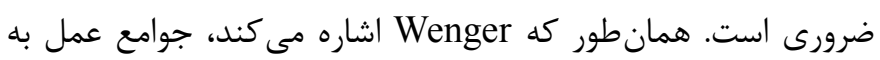
عنوان بخش اجتماعى مهمى از يادگيرى در زمينه سيستمهاى بسيار بزرتتر محسوب مىشوند. اين سيستمهاى بزرگتر مجموعهاى از جوامع عمل همبسته هستند (9q). در كليات طرح اجرايى كارورزى رشته هاى تربيت معلم از سه گروه كميته كارورزى استان، كارگروه كاروزى يرديس و كارگروه كارورزى مدرسه ياد شده است (·ץ). كه مى توان به عنوان جوامع عمل از آنها بهره برد، در صورتى كه تركيب اعضا و دسترسى دانشجو_معلمان به اين كارگروهها ممكن شود. اين جوامع عمل همگرا در دل سيستهم ياد "عضويت" در جوامع عمل مى تواند تنها در عرض جند هفته يا كمتر وجود داشته باشد، (r) ساختار يويا و روان جوامع اين امكان را فراهم مى كند كه اعضاى آن در جوامع عمل جند جانه و همگرا عضويت داشته

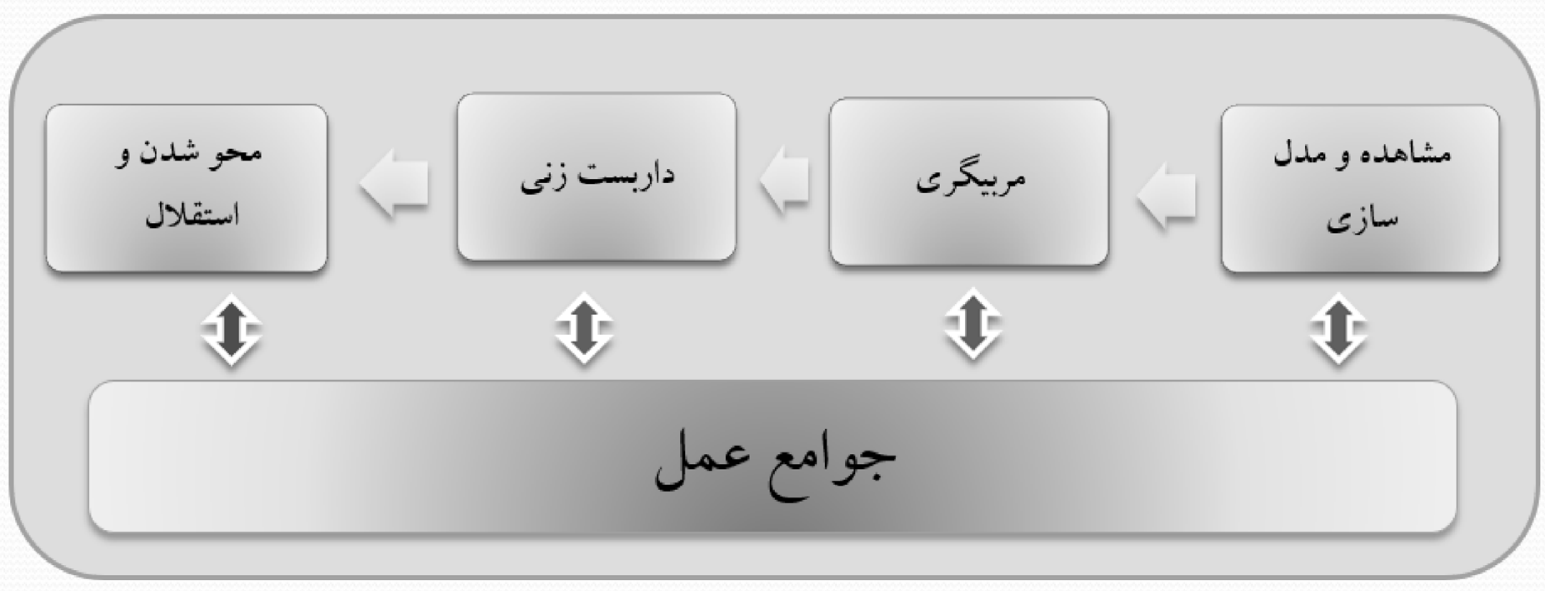

شكل r. راهبردهاى ياددهى يادخيرى برنامه درسى شناخت موقعيتى (اقتباس از Collins و همكاران و Lave و Wenger) 
برنامه درسى تربيت معلم اين است كه ارزيابى معتبر بايد به گونهاى طراحى شود كه مربوط و متصل به فرآيند و همجنين محصول مشاركت در محيط يادكيرى باشد. بر اين مبنا، ارزيابى يادكيرى موقعيتى مى تواند

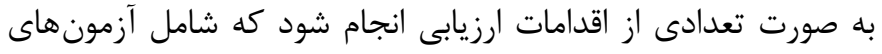
رسمى نيست بلكه شامل مواردى جون يوشه كار، نظرات متخصصان،

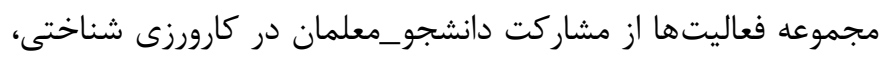

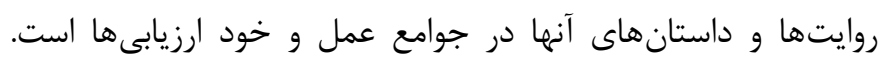

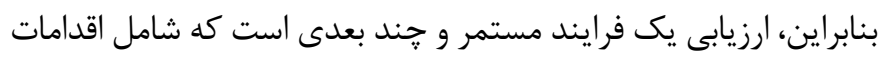

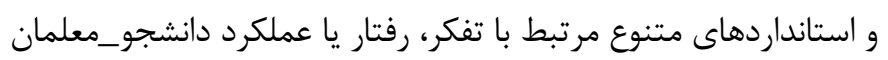
خواهد بود. به طور كلى ارزشيابى برنامه درسى در نظريه شناخت موقعيتى به دو صورت تراكمى و يايانى صورت مى كيرد.

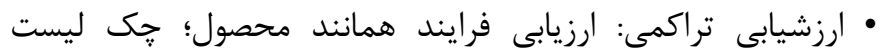
مشاركت در فعاليتهاى يادكيرى. جكى ليست مشاهدات معلم از از

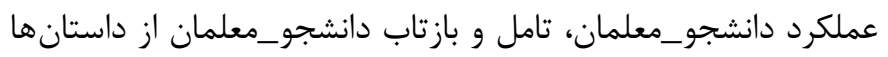
و وروايتهاى بيان شده در جوامع عمل

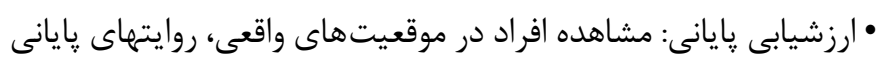
نكاشته شده

\section{دحث} نظريه شناخت موقعيتى از نظر نوع نگاهى كه بر دانش و يادگيرى دارد،

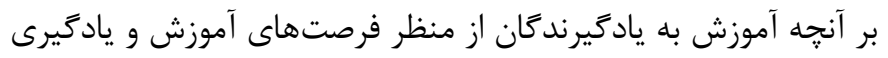

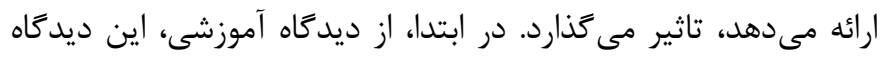
ممكن است به نفع حركت آموزش از نظامهاى آموزشى به طور كل و

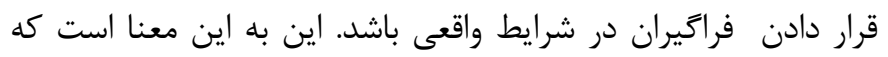

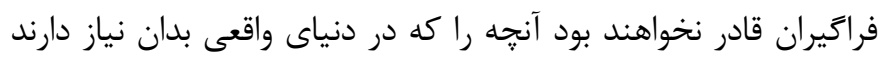

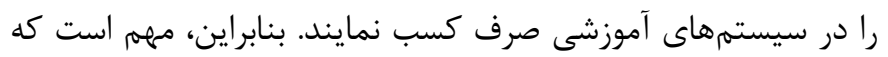
سيستمهاى فعاليتى (Activity Systems) در محيط كار را به عنوان بخشى از فر آيند طراحى آموزشى بررسى شود. اين سيستمها شامل افراد، ابزارها، ساختار فرهنكى و اجتماعى نظير طبقه نيروى كار، هنجار و قوانين است كه در تعاملات متقابل مشاركت دارند. مشخصههاى سيستمهاى

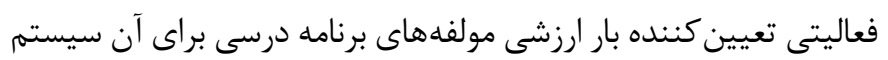

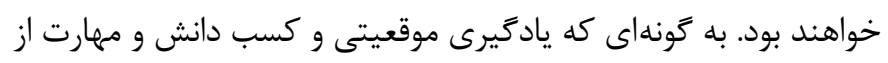

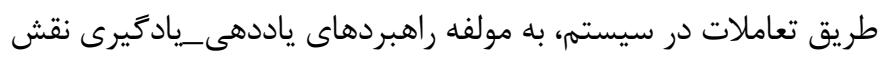

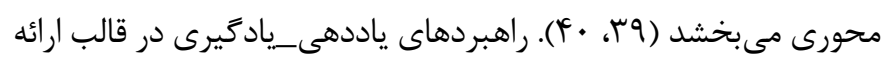

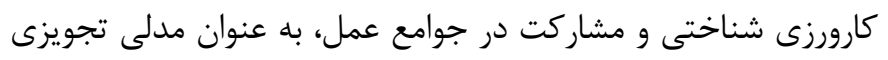

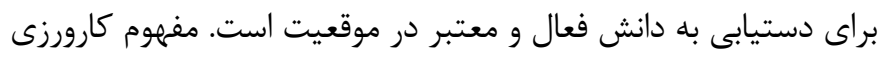

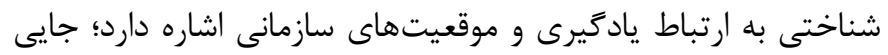

كاروزى شناختى به ارزشيابى از طريق مهارتهاى شناختى وابسته است، جرا كه يادگيرى در نظريه شناخت موقعيتى به رابطه شفاف بين فرآيند و محصول همانند يادگيرى مهارتهاى فيزيكى اشاره ندارد. ارزيابى مهارتهاى شناختى به دو ابزار كليدى وابسته است. اولا، تامل در مورد تفاوت بين تازهواردان و متخصصان با متجلى شدن تلاشهاى بين متخصص و تازه وارد كه با عنوان لابازيخش انتزاعى (Abstracted اشاره شده است. تفاوت بين تلاشهاى متخصص و تازهواردان (replay در زمينه يك مسئله مشترك، عملكرد متخصص را به عنوان مبنايى براى تعديلهاى تدريجى در عملكرد يادگيرندگان قرار مى دهد. بازيخش انتزاعى بر مشاهدات و مقايسههاى مستقيم يادگيرندكان بر مشخصههاى معين عملكرد خود و عملكرد متخصص با برجسته كردن ويزگگى ها و مشخصهها در توضيحات كلامى و يا در برخى از حوزهها، با استفاده

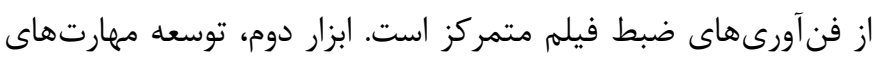
خود ارزيابى (Self-correctios) و خود نظارتى (Self-monitoring) هنگَام انجام فعاليت بيجيده است. بنابراين، كارورزى شناختى شامل توسعه و برونريزى (Externalization) گفتمان توليد كننده منتقدانه است كه يادگيرندگان مىتوانند به توليد (Producer-critic dialogue) تدريج درونريزى (Internalize) كنند. اين توسعه و برونريزى از طريق بحث، تبادل نقش هاى فراخير_مربى و حل مسئله گروهى محقق مى شود. اين فرآيند طى مفهوم تدريس متقابل (Reciprocal teaching) صورت مى گيرد كه ياد گيرند به اين ترتيب، آنها نه تنها بايد قادر به توليد سوالات و خلاصههاى خود

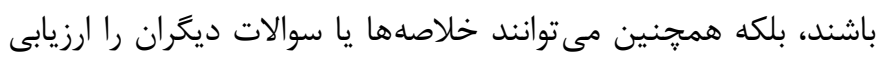
كنند. با تبديل شدن به منتقدان و همجنين توليدكنند دانش خود را درباره موضوعات و مسائل بيان مى كنند (ع). بنابراين، ارزيابى يادكيرى موقعيتى با استفاده از آزمونها و روشهاي هایى سنتى صورت نخواهد گرفت، جرا كه تاكيد آنها بر يادآورى دانش و رويه هاى واقعى به خاطر سيرده شده به جاى تامل فردى است. Young يادآور مىشود كه 》ارزيابى ديخر نمى تواند به عنوان يك افزودنى به يكى به به به طراحى آموزشى يا صرفا به عنوان مراحل جداكانه در فرآيند خطى ييش

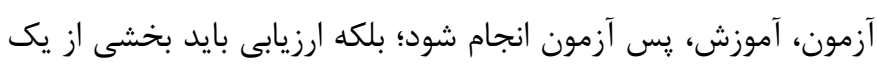
محيط تلفيقى، مداوم و يكيارجه از محيط يادگيرى تبديل شوده (ع) (ه).

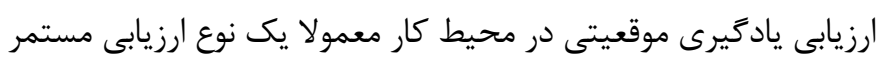

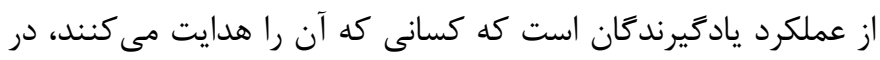
مورد كيفيت كار انجام شده و ظرفيت و توانايى هاى انجامدهندگان آن

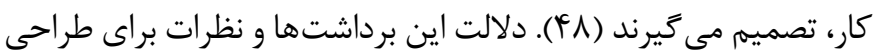




\section{نتيجه كَيرى}

يزوهش حاضر شناخت موقعيتى را به عنوان يك خارجوب يادگيرى مناسب براى حمايت و هدايت راهبردهاى يادگيرى برنامه درسى تربيت معلم پيشنهاد داده است كه مىتواند براى دستيابى به معلم يِيشرو، فكور و يزوهنده استفاده شود. استفاده از نظريه شناخت موقعيتى به عنوان :ار جوب در تبيين مولفههاى برنامه درسى تربيت معلم با نخاهى

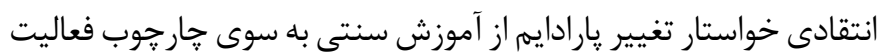

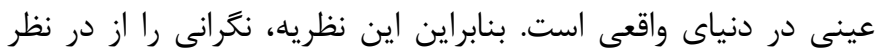
كرفتن مبناى آموزش مفاهيم و مفروضات مرتبط با مؤسسات آموزشى و شيوههاى آموزشى به سوى مبناى مهمى براى تفكر در مورد محيطهاى كار تغيير مىدهند. شناخت موقعيتى، جارجوبى براى تربيت معلم در يك فعاليت اجتماعى فراهم مى كند كه عواملى جون ذهن، بدن، فعاليت و تعاملات و موقعيت معتبر در آن دخيل هستند. بنابراين، فعاليتها و

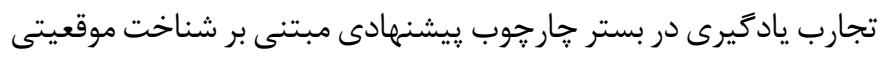

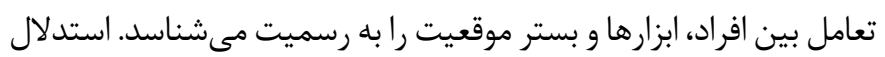
استفاده از نظريه شناخت موقعيتى در طراحى محيطهاى يادكيرى و همجنين فرايندهاى ياددهى و يادكيرى تربيت معلم بر آن است كه اين نظريه با فراهم آوردن فرصتهايى براى انجام وظايف يِيجيده و معتبر در زمينههاى واقعى تدريس در تلاشاند تا مهارتهاى تفكر سطح بالا جون توانايى استفاده از دانش در زمينه مورد كاربرد، توانايى حل مسئله در دنياى واقعى عمل و درك استدلال متخصصان در حل مسئله را يرورش

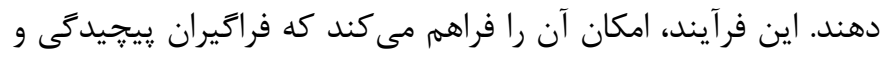

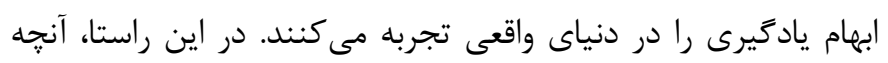
براى خارجوب برنامه درسى تربيت معلم קِيشنهاد مىشود، مشاركت

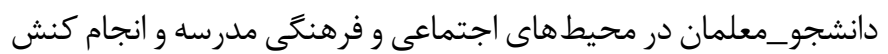
معتبر تدريس است. اين فرايند موجب تحقق اهداف دانشكاه فرهنگيان در طرح كليات برنامه درسى تربيت معلم (به ا ) مبنى بر تربيت معلمان عمل گرا، فكور و برخوردار از هويت حرفهاى خواهد شد.

\section{تشكر و قدرداذى}

يزوهش حاضر مستخرج از رساله دكترى نويسنده اول با عنوان "طراحى

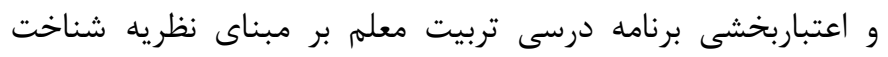

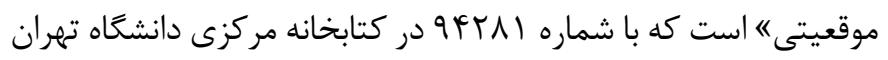
موجود است. از اساتيد راهنماى يزوهش حاضر، دكتر محمود تلخابى و دكتر مرضيه دهقانى كمال سياس و قدردانى را دارم. همجنين از ستاد توسعه علوم و فناورىهاى شناختى كه رساله حاضر را حمايت مالى

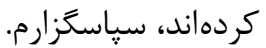

كه يادَيرى اتفاق مىافتد و يادگيرى شكلى از مشاركت در فعاليتهاى واقعى محيط كار جهت اكتساب دانش عملى تعريف مىشود ( (، ؟، 9). بر مبناى اين تبيين، يزوهش حاضر به روشنسازى جهار مولفه كليدى در برنامه درسى تربيت معلم مبنى بر هدف، فرصتهاى يادگيرى، راهبردهاى

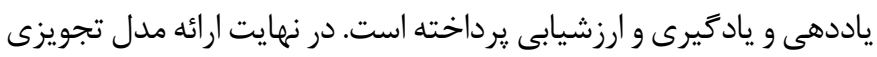
برنامه درسى تربيت معلم در قالب راهبردهاى ياددهى و يادكيرى ارائه

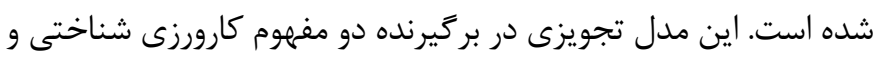
جوامع عمل، با به كاركيرى فرصتهاى يادگيرى در راستاى تحقق اهداف برنامه درسى اقدام مىنمايد و مولفه ارزشيابى مستتر در مدل تجويزى

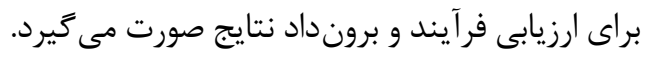

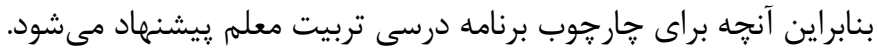
مشاركت دانشجو_معلمان در محيطهاى اجتماعى و فرهنكى مدرسه و انجام كنش معتبر تدريس در جايى كه دانش عملى حضور دارد. اين روند

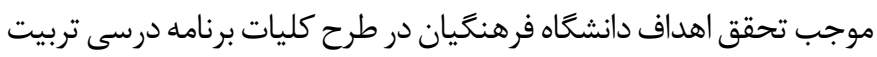

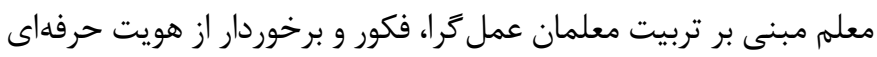
خواهد شد. تحقق اين اهداف، به بهره گيرى از كارورزى شناختى و جوامع عمل و با استفاده از يار ادايم مدل سازى، مربيخرى، داربستزنى و محو شدن اهن صورت خواهد كرفت (• (T). دانشجو_معلمان با واقع شدن در اين يارادايم از طريق فعاليت معتبر و تعامل اجتماعى با جوامع عمل فرهنگ يذير خواهند شد. اين رويكرد فرصت آن را فراهم مى كند تا دانشجو_معلمان به يادخيرى فعاليتهاى معتبر تدريس و تامل در مورد دلايل و فرضيههاى شيوههاى تدريس و ارتباط بين نظريه و عمل، كمك كنند.

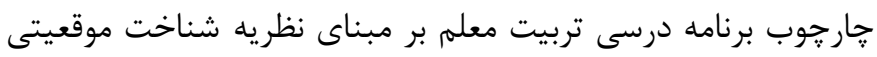

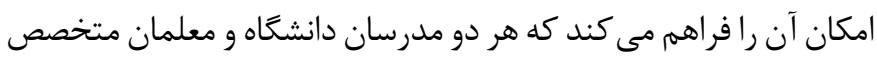

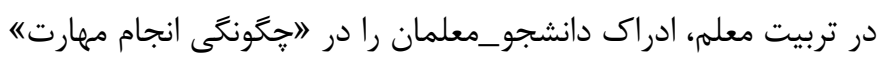
بررسى كنند و با مشاركت و تعامل در كنار يكديخر، فرصتهايى را كه مىتواند دانشجو_معلمان را تبديل به معلمان حرفهاى تبديل كند، افزايش دهند. در نهايت، بررسى نظريه شناخت موقعيتى و محيط يادَيرى معاصر موجب پيوند دو طرفه؛ كاهش يا حذف شكاف بين دانش نظرى و دانش در زمينه معتبر مىشود. به عبارت ديكر، اين

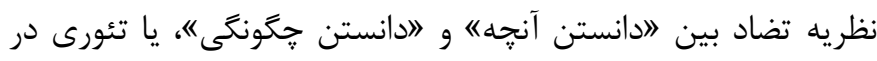

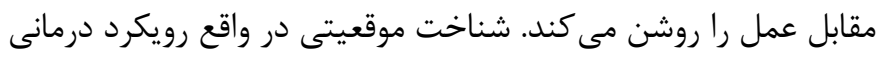

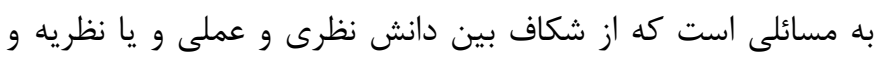
عمل بر ميخيزد؛ جايى كه دانش نظرى به جاى دانش عملى بارادايم غالب محسوب مىشود. در همين راستا نظريه شناخت موقعيتى به يكيارجهاسازى محيطهاى آموزشى و كاربردى، براى دريافت كنندكان و دارندان دانش رجوع مى كند. 


\section{References}

1. Brown JS, Collins A, Duguid P. Situated cognition and the culture of learning. Educational Researcher. 1989;18(1):32-42. 2. Lave J, Wenger E. Situated learning: Legitimate peripheral participation. Cambridge:Cambridge University Press;1991.

3. Duguid P. "The art of knowing": Social and tacit dimensions of knowledge and the limits of the community of practice. The Information Society. 2005;21(2):109-118.

4. Bereiter C. Constructivism, socioculturalism, and Popper's world 3. Educational Researcher. 1994;23(7):21-23.

5. Shulman L. Knowledge and teaching: Foundations of the new reform. Harvard Educational Review. 1987;57(1):1-23.

6. Collins A, Brown JS, Newman SE. Cognitive apprenticeship: Teaching the craft of reading, writing and mathematics. Thinking: The Journal of Philosophy for Children. 1988;8(1):2-10.

7. Saffaeimovahhed S, Mohebbat H. The sociology of education. Tehran:Ayeezh;2012. (Persian)

8. Wilson BG, Myers KM. Situated cognition in theoretical and practical context. In: Jonassen DH, Land SM, editors. Theoretical foundations of learning environments. New Jersey:Routledge;2000. pp. 57-88.

9. Greeno JG. The situativity of knowing, learning, and research. American Psychologist. 1998;53(1):5-26.

10. Kharrazi SK, Talkhabi M. The foundations of educational psychology. Tehran:Samt;2011. (Persian)

11. Roth WM, McGinn MK. Deinstitutionalising school science: Implications of a strong view of situated cognition. Research in Science Education. 1997;27(4):497-513.

12. Brown JS, Duguid P. Stolen knowledge. Educational Technology. 1993;33(3):10-15.

13. Resnick L. Shared cognition: Thinking as social practice.

In: Resnick LB, Levine JM, Teasley SD, editors. Perspectives on social shared cognition. Washington DC:American Psychological Association;1991. pp. 1-20.

14. Seel NM. Epistemology, situated cognition, and mental models: 'Like a bridge over troubled water'. Instructional Science. 2001;29(4-5):403-427.
15. Lave J. Cognition in practice: Mind, mathematics and culture in everyday life. Cambridge:Cambridge University Press; 1988.

16. Miller GA, Gildea PM. How children learn words. Scientific American. 1987;257(3):94-99.

17. Dahlgren MA, Reid A, Dahlgren LO, Petocz P. Learning for the professions: Lessons from linking international research projects. Higher Education. 2008;56(2):129-148.

18. Hodkinson H, Hodkinson P. Improving schoolteachers' workplace learning. Research Papers in Education. 2005;20(2):109-131.

19. Eraut M. Transfer of knowledge between education and workplace settings. In: Rainbird H, Fuller A, Munro A, editors. Knowledge, values and educational policy. London \& New York:Routledge;2012. pp. 75-94.

20. Ahmedi A, Moosapour N. Macro design (architecture) teacher training curriculum, national teacher training program of the Islamic republic of Iran. Tehran:Farhangian University;2014.

21. Gherardi S, Nicolini D, Odella F. Toward a social understanding of how people learn in organizations: The notion of situated curriculum. Management Learning. 1998;29(3):273297.

22. Short EC. Forms of curriculum inquiry. [Mehrmohammadi M, et al, Trans]. Tehran:Samt;1991. (Persian)

23. Dehghani M, Amin Khandaghi M, Jafari Sani H, Noghani Dukh Bahmani M. The study of conceptual model in curriculum field: criticize of researches have been done with model design approach in curriculum. Foundations of Education. 2011;1(1):99-126. (Persian)

24. Wilson AL. The promise of situated cognition. New Directions for Adult and Continuing Education. 1993;1993(57):7179.

25. Greeno J, Moore J, Smith DR. Transfer of situated learning. In: Detterman DK, Sternberg RJ, editors. Transfer on trial: Intelligence, cognition, and instruction. New Jersey:Ablex Publishing Corporation;1993. pp. 99-167 
26. Safarnavade Kh, Al Hisseunu F, Soleimani Aghchay M, Hosseinzadeh Gh, Ahmadi FZ, Elhamian N, et al. A practical guide to the internship program of Farhangian University with approach to training a thoughtful teacher. Tehran:Farhangian University;2016. (Persian)

27. Greeno JG. On claims that answer the wrong questions. Educational Researcher. 1997;26(1):5-17.

28. Choi JI, Hannafin M. Situated cognition and learning environments: Roles, structures, and implications for design. Educational Technology Research and Development. 1995;43(2):53-69.

29. Billett S. Workplace learning: Its potential and limitations. Education + Training. 1995;37(5):20-27.

30. Billett S. Workplace pedagogic practices: Co-participation and learning. British Journal of Educational Studies. 2002;50(4):457-481.

31. Wilson BG. Situated instructional design: Blurring the distinctions between theory and practice, design and implementation, curriculum and instruction. In the meeting of the Association for Educational Communications and Technology (AECT). February 1995; Anaheim, CA, USA;1995.

32. Bereiter C, Scardamalia M. Surpassing ourselves. An inquiry into the nature and implications of expertise. Chicago:Open Court;1993.

33. Harley S. Situated learning and classroom instruction. $E d-$ ucational Technology. 1993;33(3):46-51.

34. Rogoff B. Observing sociocultural activities on three planes: Participatory appropriation, guided appropriation and apprenticeship. In Wertsch J, Rio P, Alvarez, A, editors. Sociocultural studies of the mind (Learning in doing: Social, cognitive and computational perspectives). Cambridge:Cambridge University Press;1995. pp. 139-164.

35. Billett S. Workplace participatory practices: Conceptualising workplaces as learning environments. Journal of Workplace Learning. 2004;16(6):312-324.

36. Billett S. Learning in the circumstances of practice. International Journal of Lifelong Education. 2014;33(5):674-693.
37. Billett S. Learning through work: Workplace affordances and individual engagement. Journal of Workplace Learning. 2001;13(5):209-214.

38. Vygotsky LS. Mind in Society: The development of higher psychological processes. Cambridge:Harvard University Press; 1980.

39. Engeström Y. Expansive visibilization of work: An activity-theoretical perspective. Computer Supported Cooperative Work (CSCW). 1999;8(1-2):63-93.

40. Engestrom Y. Activity theory as a framework for analyzing and redesigning work. Ergonomics. 2000;43(7):960-974.

41. Compton P. Situated cognition and knowledge acquisition research. International Journal of Human-Computer Studies. 2013;71(2):184-190.

42. Farahani A, Nasr Esfahani A, Sharif Khalifeh Soltani M. A study method of elementary school teachers training in teacher training center. Journal of Technology of Education. 2009;5(1):61-75. (Persian)

43. Salsabili N. Teacher training; The need for transformation in structure and organization. Educational Research Letter. 2005;89:6-11. (Persian)

44. Sha'bani Z. Comparative study of teacher education program in Iran and several countries. Quarterly Journal of Education. 2004;79:121-160. (Persian)

45. Bennett D. The use of learner-generated drawings in the development of music students' teacher identities. International Journal of Music Education. 2013;31(1):53-67.

46. De Bruijn HF. Cognitive apprenticeship in a CAL-environment for functionally illiterate adults. Instructional Science. 1995;23(4):221-241.

47. Woolley NN, Jarvis Y. Situated cognition and cognitive apprenticeship: A model for teaching and learning clinical skills in a technologically rich and authentic learning environment. Nurse Education Today. 2007;27(1):73-79.

48. Billett S. Learning through practice: beyond informal and towards a framework for learning through practice. Revisiting global trends in TVET: Reflections on theory and 
practice. Bonn:UNESCO-UNEVOC International Centre for Technical and Vocational Education and Training;2013. pp. 123-163.

49. Wenger E. Communities of practice and social learning systems: The career of a concept. In: Blackmore C, editors. Social learning systems and communities of practice. London:Springer;2010.

50. Vanderbilt CA. Anchored instruction and situated cognition revisited. Educational Technology. 1993;33(3):52-70.

51. Gessler. M. Situated Learning and Cognitive Apprenticeship. In: Maclean R, Wilson D, editors. International handbook of education for the changing world of work. Dordrecht:Springer;2009. pp. 1161-1625.

52. Rogoff B, Gardner W. Adult guidance of cognitive devel- opment. In Rogoff B, Lave J, editors. Everyday cognition: Its development in social context. Cambridge:Harvard University Press;1984. pp. 95-116.

53. Wenger E, McDermott RA, Snyder W. Cultivating communities of practice: A guide to managing knowledge. Brighton:Harvard Business Press;2002.

54. Hooper S. Cooperative learning and computer-based instruction. Educational Technology Research and Development. 1992;40(3):21-38.

55. Wenger E. Communities of practice: Learning, meaning, and identity. Cambridge:Cambridge University Press;1999.

56. Young MF. Instructional design for situated learning. Educational Technology Research and Development. 1993;41(1):43-58. 